\title{
Economic Reform, Growth and Democracy During \\ Post-communist Transition
}

\author{
By: Jan Fidrmuc
}

Working Paper No. 372

March 2001 


\title{
Economic Reform, Democracy and Growth during Post- communist Transition
}

\author{
Jan Fidrmuc
}

\section{Center for European Integration Studies (ZEI), University of Bonn; CPB Netherlands Bureau for Economic Policy Analysis, The Hague; and Centre for Economic Policy Research (CEPR), London.}

\author{
March 2001
}

\begin{abstract}
This paper explores interactions between growth, economic liberalization and democratization during transition. The results can be summarized as follows: (1) Liberalization has a strong positive effect on growth during transition (also when controlling for endogeneity of liberalization in growth). (2) Democracy facilitates economic liberalization. (3) Because of its effect on liberalization, democracy has a positive overall effect on growth. Nevertheless, the marginal effect of democracy (after controlling for progress in economic liberalization) is negative during early transition. (4) The progress in democratization in turn depends on past economic performance in a surprising manner-the relationship between past growth and subsequent democracy appears negative. (5) Economic performance is an important determinant of electoral outcomes and, in particular, of support for reforms.
\end{abstract}

Keywords: Democracy, Liberalization, Economic Performance, Elections. JEL codes: E63, O11, P26, P27.

* A previous version of this paper was entitled "Liberalization, Democracy and Economic Performance during Transition." I benefited from comments and suggestions from Nauro Campos, Ariye Hillman, Klarita Gërxhani, Sylviane Guillaumont, Jürgen von Hagen, Philipp Harms, Mathilde Maurel, Ariane Tichit, Patrick Paul Walsh and Charles Wyplosz, as well as participants of the $9^{\text {th }}$ Silvaplana Workshop on Political Economy, the European Public Choice Society meeting in Siena, CEPR/WDI/EBRD conference in Moscow, the "Money Doctors" conference in Paris and seminars at CentER, ZEI, SITE, CERDI and Trinity College Dublin.

${ }^{\dagger}$ Address: ZEI, Walter-Flex-Strasse 3, 53113 Bonn, Germany. Email: JFidrmuc@ uni-bonn.de. Phone: +49228-73-1821, Fax: +49-228-73-1809. Web: http://www.tbns.net/fidrmuc/. 
Acknowledgements:

A previous version of this paper was entitled "Liberalization, Democracy and Economic Performance during Transition." I benefited from comments and suggestions from Nauro Campos, Ariye Hillman, Klarita Gërxhani, Sylviane Guillaumont, Jürgen von Hagen, Philipp Harms, Mathilde Maurel, Ariane Tichit, Patrick Paul Walsh and Charles Wyplosz, as well as participants of the $9^{\text {th }}$ Silvaplana Workshop on Political Economy, the European Public Choice Society meeting in Siena, CEPR/WDI/EBRD conference in Moscow, the "Money Doctors" conference in Paris and seminars at CentER, ZEI, SITE, CERDI and Trinity College Dublin.

Jan Fidrmuc

Center for European Integration Studies (ZEI)

University of Bonn

Walter-Flex-Strasse 3

53113 Bonn

Germany

Phone: +49-228-73-1821

Fax: +49-228-73-1809

Email: JFidrmuc@uni-bonn.de

\section{Non-Technical Summary}

After the countries of Central and Eastern Europe and the former Soviet Union cast off communism, they generally set out (at least initially) to implement economic and political reforms simultaneously. This stands in contrast with previous successful transitions in countries such as Chile, South Korea and Taiwan (where political liberalization followed only after economic reforms were well under way), or the current transition in China (where economic liberalization unfolds with little simultaneous democratization). Nevertheless, despite the similarities at the outset, the 25 countries in transition subsequently displayed a large degree of variation in their approaches to economic liberalization and democratization, as well as in economic performance. While some countries sustained the momentum and succeeded in implanting important elements of democracy and the market economy, others essentially returned to being autocracies with overwhelming state interference in the economy. The countries in the region lived through economic collapses dwarfing the Great Depression, military aggressions, civil wars, coup d'états, surge of crime and violence, but also resumption of growth and accelerating integration with Western Europe. 
This variation of approaches and outcomes raises several important questions. Did democracy facilitate or constrain progress in economic liberalization? Was there a trade-off between democracy and growth? Did the countries that stalled or reversed the initial democratization gain in terms of their subsequent growth? Was there indeed a case for a benevolent dictator who would be in a better position to implement efficiency-enhancing reforms while temporarily postponing democratization?

A-priori, the answers to these questions are not obvious. Several studies have argued that democracy is a precondition for sustained long-term growth and economic prosperity because it guarantees the rule of law and contract enforcement. On the other hand, democracy introduces important political constraints that may affect the actions of the government and/or limit its ability to proceed with the needed but costly reforms (for example, by allowing for reform-minded governments to be toppled in democratic elections). Similarly, democracy may increase uncertainty about future policies, as a future government may not necessarily continue policies or live up to commitments of the current one. Overall, it is far from clear which of these factors is more important during the transition. The empirical evidence on the relationship between democracy and growth in market economies is mixed at best. For the transition economies, it is essentially non-existent.

The present paper explores interactions between democratization, economic liberalization and growth during post-communist transitions in Central and Eastern Europe and the former Soviet Union. The results can be summarized as follows: (1) Liberalization has a strong positive effect on growth during transition. This holds also when controlling for possible endogeneity of liberalization in growth (progress in liberalization does, however, appear to depend crucially on initial conditions). (2) Democracy encourages liberalization (in the context of Granger causality, democracy causes liberalization). Countries, which introduced greater democracy, subsequently progress further in economic liberalization too. (3) Because of its reinforcing effect on liberalization, democracy has a positive overall impact on growth. Nevertheless, the marginal effect of democracy (after controlling for the progress in economic liberalization) was negative during early part of transition. (4) The progress in democratization in turn depends on past economic performance in a surprising manner-the relationship between past growth and subsequent democracy appears negative (further research may be necessary to illuminate this result). (5) Economic performance is an important determinant of electoral outcomes and, in particular, of support for reforms. Support for parties associated with reforms falls with unemployment and increases with 
growth, output level relative to 1989 and, somewhat surprisingly, inflation. Progress in economic liberalization lowers political support for reform parties, but the extent of democracy is positively correlated with support for reforms in elections.

\section{Introduction}

After the communist regimes collapsed throughout Eastern Europe and the former Soviet Union, they were replaced (at least initially) by relatively wide-ranging democracy. Measured by the indices of political freedom and civil liberties published by the Freedom House (see www.freedomhouse.org), by 1993 - two to three years after the transition began-the Czech Republic, Hungary and Slovenia attained the same extent of democracy as the United Kingdom or Germany. Although other countries did not democratize as rapidly as the three front-runners, they also made considerable progress. Between 1989 and 1991, the average of the two Freedom-House indices rose from 0.26 to 0.57 , on a scale from zero (no democracy) to one (full democracy).

The high speed of democratization reflected not only the desire of these countries' citizens to live in democracy, but also the encouragement or outright pressure from Western governments, international organizations, and especially the European Union, which made democracy an explicit precondition for accession negotiations. This approach, simultaneous implementation of political and economic reforms (in fact, political reforms often even preceded the economic ones), stands in sharp contrast with the experience of countries such as Chile, Taiwan and South Korea, where democratization followed only after economic liberalization proved successful, or with the current Chinese approach based on economic liberalization without democratization.

Ten years later, however, democracy and prosperity are far from prevailing universally in the former communist countries. Overall, the outcomes in terms of economic performance and political developments have been very diverse. While some countries have been successful in sustaining the reform momentum and eventually resuming growth, others experienced reform reversals, reemergence of authoritarian regimes and/or protracted economic decline. The objective of this paper is to analyze the mutual interactions between economic performance, economic liberalization and democratization during the transition. Has simultaneous introduction of economic and political reforms adversely affected the

\footnotetext{
${ }^{1}$ It should be emphasized, however, that the Freedom House indices only measure the extent of democracy in a given year. Obviously, the tradition of democracy, built up only gradually, is of crucial importance as well.
} 
ability of the transition countries to proceed with economic liberalization-for example, by imposing political constraints on the speed of reform (see Roland, 2000)? Is there a trade-off between democracy and growth? Have the countries that postponed or reversed democratization been able to grow faster than the more democratic ones?

The literature offers an abundance of opinions but no consensus on the effect of democracy on economic growth. On the one hand, North (1991, 1993) and Olson (2000) argue that democracy is a precondition for sustained long-term growth and prosperity, because it guarantees the protection and enforcement of property rights. Similarly, Rodrik (2000) posits that democracy leads to higher growth because it lowers economic uncertainly, delivers better institutional outcomes and results in better response to adverse shocks. Indeed, Rodrik suggests that democracy is a meta-institution that facilitates creation of other growthenhancing institutions. Minier (1998) finds that the countries which democratized appear to grow faster than ex-ante similar countries without democratization. In contrast, empirical studies based on large cross sections of countries suggest that the relationship is negative (Helliwell, 1994) or hump-shaped (Barro 1996, 1999), but not robustly so (see Przeworski and Limongi, 1993). Barro explains the negative effect of democracy (beyond a moderate level) on growth by pointing out that democratic countries typically implement excessive redistribution programs. Democracy may also lead to inefficient policy outcomes, especially in case of economically costly policies. Fernandez and Rodrik (1991) show that rational voters may choose not to support efficiency-enhancing reform because of individual uncertainty about the resulting payoffs. Such a reform would be sustained ex post once implemented (for example by a benevolent dictator) but would be rejected if subjected to a vote ex ante. Similarly, Alesina and Drazen (1991) illustrate how war of attrition over asymmetric payoffs may lead to efficiency-enhancing reforms being delayed. Finally, governments facing elections may pursue policies that maximize the prospects of reelection, even if these are detrimental to long-term economic growth.

The experience of post-communist countries can shed new light on the relationships between democracy and growth. The transition process can be seen as essentially a controlled experiment, involving 25 countries with little or no initial democracy and ex-ante similar (though not identical) in terms of economic development. Subsequently, the paths followed by the individual countries in terms of economic and political liberalization diverged dramatically, with some introducing democracy and economic freedom essentially at level with Western Europe, and others reverting to authoritarian rule and central planning. By 
observing the variety of approaches to democratization as well as the respective economic outcomes, one can infer new insights about the importance of democracy for economic performance. These insights can have important implications not only for transition countries, but also for developing countries contemplating economic and/or political liberalization.

The empirical results obtained with a sample of 25 transition economies suggest that, overall, democracy is good for growth because it reinforces economic liberalization (which in turn has a strongly positive effect on growth). However, the marginal effect of democracy after controlling for progress in economic liberalization appears negative during the initial transition period. Hence, democracy alone, if unaccompanied by a correspondingly economic liberalization, harmed growth performance immediately after the collapse of communism.

The analysis then turns to exploring the effect of economic performance on political developments. While essentially all transition countries introduced at least a moderate level of democracy initially, the subsequent developments differed substantially-either because of the unwillingness of political elite to introduce and sustain wide-ranging democracy, or because the reform-minded government failed to sustain political support. Somewhat surprisingly, progress in democratization during the later transition period (1994-98) appears negatively related to past growth (over 1990-93). Hence, the countries that experienced deeper output contractions early in the transition in turn implemented greater democracypossibly because of political changes instigated by the adverse economic outcomes.

The final part of the analysis looks closer at determinants of electoral outcomes (using a sample of 17 elections in 7 countries of Central and South-Eastern Europe). The support for pro-reform parties falls with unemployment, and rises with economic growth, output level (relative to 1989) and, somewhat surprisingly, inflation. Progress in economic liberalization, however, reduces the support for reforms, as the costs of reforms apparently go beyond deteriorating economic performance. In contrast, the level of democracy increases the support for reforms.

The next section takes stock of the main economic outcomes of the transition in 25 countries of Central and Eastern Europe (CEE) and the former Soviet Union (FSU) and briefly surveys the literature attempting to explain the differences in economic performance among the post-communist countries. Section 3 introduces the analytical framework and explores the relationship between economic liberalization and growth. Section 4 investigates the effect of democracy on growth and section 5 analyzes the determinants of democracy 
during transition. Section 6 looks at one of the main sources of differences in political developments—electoral outcomes. Finally, section 7 concludes.

\section{Explaining Growth Performance during Transition}

The economic outcomes of transition have been very diverse: while some countries resumed growth after two to four years of recession, others experienced deep and protracted collapse of economic activity without much subsequent recovery. Table 1 reports some basic indicators of economic performance for 25 transition countries. According to the official statistics, economic activity virtually collapsed in many post-communist countries. By 1998, real GDP shrank to between 25 and $83 \%$ of the level attained in 1989 (Georgia and Uzbekistan, respectively, were the two extremes). The average cumulative output fall across the 25 countries listed in Table 1 was $42 \%$. This transition-induced contraction easily dwarfs that reported by the US during the Great Depression (34\%). The output fall was also relatively long-lasting, the average duration of the depression was 5.6 years, 4.2 years in CEE and the Baltics and 7 years in the FSU. The subsequent cumulative increase of GDP was disappointingly small, $10 \%$ on average. As of 1998, only in Poland and Slovenia exceeded the pre-transition (1989) level of output. In contrast, Russia, Ukraine, Moldova and Kazakhstan, reported essentially no recovery.

\section{Insert Table 1 about here.}

It is generally accepted that the official statistics exaggerate the severity of the output fall. The statistics directly measure the production of medium-sized and large firms, but only estimate the output of small firms, which make up most of the new and growing private sector. Over-reporting under communism (in order to meet targets stipulated by the central plan) and under-reporting at present (for tax purposes) also play a role. Furthermore, the official statistics fail to properly account for the transfer of economic activity from the official to the unofficial economy. Finally, a part of the output fall may be due to elimination of unmarketable production, reduction of waste, as well as a fall in inventories as the shortage economy turned into a surplus one (which per se is associated with greater efficiency). Nonetheless, even if overestimated by official statistics, the reform-induced output fall in CEE and FSU was undoubtedly very severe.

Several theoretical explanations have been suggested to account for the output fall. Calvo and Coricelli (1993) attribute the contraction to credit restrictions, and high real interest rates 
due to overly restrictive monetary policy. Blanchard and Kremer (1997), and Roland and Verdier (1999) develop supply-side explanations. Accordingly, output fell because of disorganization of supplier-buyer relationships due to asymmetric information about outside options in bargaining (Blanchard and Kremer), or search frictions and relation-specific investment (Roland and Verdier), respectively. Hillman and Ursprung (2000) suggest that the output fall occurred because economic and political reforms were not accompanied by a change of political culture. They argue that as the political culture of rent seeking remained in place, time and resources spent for rent-seeking activities even increased, thus precipitating the output fall.

The empirical literature, on the other hand, focused primarily on assessing the impact of the choice of reform strategy (shock therapy vs. more gradual reform) on economic performance during transition. This focus was spurred by the contribution of De Melo et al. (1996). They constructed annual liberalization indices assessing transition economies' progress in three areas, liberalization of the internal markets, liberalization of the external markets, and privatization and restructuring, between 1989 and 1994. These indices were then used to construct a measure of cumulative liberalization (cumulative liberalization index, CLI), defined as the sum of yearly weighted-average indices (with weights $0.3,0.3$ and 0.4 , respectively). Using the CLI as an explanatory variable for economic performance, they found that greater liberalization was associated with higher growth and lower inflation (both averaged over 1993-94). This finding inspired a host of subsequent contributions, some reaching similar conclusions (e.g. Sachs, 1996; and Fischer et al., 1996, 1997; Selowsky and Martin, 1997), others disputing them.

In particular, Åslund et al. (1996) show that the relationship between liberalization and average growth over 1989-95 turns out insignificant after including dummies for the ruble zone (including the Baltics) and war-torn countries. Åslund et al. interpret this result as proving the overwhelming importance of initial conditions. Accordingly, favorable initial conditions explain both the greater progress in liberalization as well as better economic performance of Central European countries. ${ }^{2}$ Heybey and Murrell (1999), Krueger and Ciolko (1998) and Popov (2000) put forward similar arguments, using more elaborate analytical

\footnotetext{
${ }^{2}$ However, this result highlights an important problem inherent to the construction of the CLI. The FSU countries started liberalizing later and therefore their CLI's are by definition lower. The ruble-zone dummy then proxies for cumulative liberalization and effectively divides the post-communist countries into groups with high and low cumulative liberalization. Given the small sample size ( 24 countries), the CLI itself then turns out insignificant.
} 
techniques. Krueger and Ciolko show that the progress in cumulative liberalization (measured by the CLI) can indeed be explained by regressing it on a dummy for the FSU, GNP per capita as of 1988 and the ratio of exports to GDP. More importantly, they argue that the CLI is endogenous in output decline-countries that experienced lower contraction of output were able to liberalize faster. Heybey and Murrell estimate a system of simultaneous equations to show that there is in fact two-way causation between economic growth and the speed of liberalization (measured as the change in the annual liberalization index ${ }^{2}$ ).

Finally, Berg et al. (1999) evaluate the relative importance of the initial conditions and the progress in liberalization for growth performance and find that the initial output fall is attributable primarily to initial conditions and macroeconomic instability whereas the effect of liberalization on growth was overwhelmingly positive. When considering separately the effects of liberalization on state and private sectors, they conclude that liberalization contributed to the contraction in the state sector but this was more than compensated by the expansion in the private sector. This finding is similar to those of Havrylyshyn et al. (1998) and Wolf (1999) who show that liberalization has a J-curve effect on output growth-a negative contemporaneous effect is more than compensated by subsequent gains (at one and two-year lags).

\section{Liberalization, Initial Conditions and Growth}

This section explores the relationship between liberalization and growth in a cross section of 25 transition countries. The progress in implementing economic reforms is measured by the liberalization index of de Melo et al. (1996) and the subsequent progress-in-transition indicators published by the European Bank for Reconstruction and Development (EBRD). The two series have been linked up by Havrylyshyn et al. (1998) into a single time series covering the entire transition period. ${ }^{[}$The analysis is performed with averages of all variables over longer periods (cf. Havrylyshyn et al., 1998; Berg et al., 1999; and Wolf, 1999, who use annual data). This approach should minimize the noise in the data, due to measurement errors or short-term fluctuations caused by external factors. On the other hand, a disadvantage is the

\footnotetext{
${ }^{3}$ Heybey and Murrell (1999) rightly criticize the CLI because it reflects neither the level nor the speed of reform. The former is measured by the annual liberalization index whereas the latter is captured by the change of the annual index. The more recent literature typically uses the annual liberalization index rather than the CLI.

4 The EBRD publishes annually the following indicators: large-scale privatization, small-scale privatization, governance and enterprise restructuring, price liberalization, trade and foreign-exchange liberalization, competition policy, banking reform and securities markets.
} 
lower number of degrees of freedom. To partially remedy this problem, I split the period under consideration into two sub-periods, 1990-93 and 1994-98, and run pooled regressions over both sub-periods (nevertheless, for comparison, I also present results of separate regressions for the early transition period and the later period).

As is standard in the empirical growth literature, I estimate most regressions with the growth rate of per-capita GDP as the dependent variable. Nevertheless, since the previous literature on growth patterns during transition typically used the growth rate of overall GPD, I present results with this dependent variable as well. The explanatory variables are the liberalization index, a proxy for initial conditions (distance from the country's capital to Brussels), a dummy for countries engaging in military conflicts, secondary school enrolment, and initial income per capita. I tried including also other variables typically found significant in the growth literature, in particular the investment rate, but they turned out insignificant.

Initial conditions are proxied using the distance from Western Europe (measures as distance between the country's capital and Brussels). ${ }^{6}$ This is intended as a measure of factors such as historical legacies, social, cultural and religious traditions, institutional factors and economic development. In addition, it also reflects the cost of engaging in economic relations with Western Europe. The distance replaces the typically used dummy for the former Soviet Union. Unlike the FSU dummy, it provides a continuous measure of initial conditions: undoubtedly, the initial conditions in Estonia were dramatically different from those in, for example, Tajikistan. The liberalization index is negatively correlated with the distance from Western Europe: the correlation coefficient between the distance and the liberalization index for 1990-93 (1994-98) is -0.74 (-0.66). Hence, the further a country lies from Brussels, the more reluctant it was to implement radical economic reforms. In addition to the distance from Western Europe, a dummy for countries affected by military conflicts (Croatia, Macedonia, Armenia, Azerbaijan, Georgia and Tajikistan) is also included in the regressions.

Overall, the impact of liberalization on growth (see Table 2) is positive and strongly significant. The regression reported in column 2 includes an interaction term between the liberalization index and a dummy for 1994-98. The coefficient on this interaction term indicates that liberalization had a more powerful effect during the later period. This is also confirmed by separate regressions for the two sub-periods (columns 5 through 8). In column 3 , a square of the liberalization index is added to the regression, which results in better overall

\footnotetext{
${ }^{5}$ The resulting series thus covers 1989-98. I am grateful to Ron van Rooden for sharing their data with me.
} 
fit (higher adjusted $\mathrm{R}^{2}$ ). Hence, the relationship between liberalization and growth appears non-linear (U-shaped). Liberalization worsens growth at low levels but accelerates it after a moderate level of liberalization has already been attained. Either no liberalization or complete liberalization is thus better than intermediate liberalization. The minimum effect of liberalization is attained at a value of the liberalization index around $0.35-0.39$, which is just above the level attained by Russia and Moldova. Once this minimum level has been exceeded, there are increasing returns to further liberalization. Nonetheless, the linear relationship gives a slightly better statistical fit in separate regression for the 1994-98 period (compare columns 7 and 8$)$.

\section{Insert Table 2 here.}

Krueger and Ciolko (1998) and Heybey and Murrel (1999) argue that the liberalization index is in fact endogenous in economic performance, in particular growth, as countries with favorable economic performance may find it easier to implement costly reforms. If this is the case, then the coefficient estimated by OLS for the relationship between liberalization and growth will be biased. To control for the potential endogeneity bias, I instrumented the liberalization index. The results are reported panel B of Table 2. To improve the precision of estimation, the first-stage regressions are estimated with annual observations rather than period averages. The instruments used for the liberalization index in columns 9 through 11 are the following: lagged value of the liberalization index, initial GNP per capita, number of years the country spent under communism, war dummy and a quadratic transition-time trend. In $_{\text {In }}$ columns 12 through 14, the lagged value of liberalization index is replaced by its value as or 1989 (thus the second set of instruments contains only pre-transition variables so as to completely rule out the endogeneity bias). With both sets of instruments, the estimated impact of liberalization on growth remains significant and positive-in fact, it turns out even stronger (compare, for example, columns 7, 11 and 14). Hence, liberalization has a positive and statistically significant effect on growth, which is apparently not due to endogeneity (although initial conditions clearly have played an important role in determining progress in economic liberalization).

The U-shaped relationship between liberalization and growth during the contraction period may be due to two effects. On the one hand, countries that postponed radical reforms

\footnotetext{
${ }^{6}$ For Kazakhstan, Kyrgyzstan, Tajikistan, Turkmenistan and Uzbekistan, the distance to Brussels is estimated as $6,000 \mathrm{~km}$.

${ }^{7}$ Transition-time trend is zero before the start of transition (see Fischer and Sahay, 2000, Figure 1).
} 
or implemented them more gradually may have succeeded in avoiding some of the adverse effects experienced by the more reform-enthusiastic countries. Nevertheless, such an intermediate reforms apparently did not prevent disorganization effects (see Blanchard and Kremer, 1997; and Roland and Verdier, 1999) from occurring eventually. On the contrary, the outcome of the intermediate reform is worse than either that of a full reform or of no reform.

Several other factors besides liberalization have been important determinants of growth during transition. The effect of being farther from Western Europe appears negative, although it is often not significant. Engagement in military conflicts, not surprisingly, is associated with substantially lower growth, by 8-10 percentage points annually. On the other hand, once the war is over, the affected countries grow more rapidly (by 3-5 percentage points annually) as they make up for the loss of output.

Secondary-school enrollment and the initial level of GNP are two of the variables typically found important in the economic growth literature-see, for example, Barro (1991), and Levine and Renelt (1992). The coefficient on initial GNP per capita is negative (but not always significant). The negative coefficient is consistent with the notion of conditional convergence, as predicted by the neoclassical growth theory-poor countries grow faster after controlling for other factors affecting growth. Secondary-school enrollment is positively correlated with growth, in particular during the later period. Other variables suggested by the growth literature, in particular primary-school enrollment and government expenditure, were generally not significant. In fact, if anything, government expenditure actually appears to have a positive effect on growth during transition (Campos, 1999, obtained a similar result). Investment (as a share of GDP) shows a significant and positive effect only during 1990-93, whereas it is insignificant and negative during the recovery (not reported). Tichit (1999) finds that investment has positive effect on growth only in the CEE countries, whereas its effect is insignificant in the FSU-this can explain the insignificant results for a cross section containing both CEE and FSU countries.

The regressions reported in Table 2 provide a rather good account of growth in the transition countries, with adjusted $\mathrm{R}^{2}$, s ranging between 0.53 and 0.80 . The most important explanatory variable is the liberalization index, which alone (along with the constant and dummy for 1994-98) produces an adjusted $\mathrm{R}^{2}$ of 0.57 (0.60 when the interaction term for liberalization during 1994-98 is included) in the pooled regression. The distance from Brussels alone results in an adjusted $\mathrm{R}^{2}$ of 0.52 . The two war dummies yield an adjusted $\mathrm{R}^{2}$ of 
0.58. Secondary school enrollment and the initial GNP per capita yield adjusted $\mathrm{R}^{2}$ of 0.46 and 0.44 , respectively.

\section{Democracy and Growth}

The transition countries implemented, at least initially, economic and political liberalization simultaneously (in many post-communist countries, political reforms in fact proceeded faster than the economic ones). This approach may have affected their economic performance in several ways. First, democracy brings about political constraints (see e.g. Roland, 2000) that may slow down progress in economic liberalization (for example, through voters' opposition to reform implementation of their support for reform reversal) and, in turn, harm economic performance during transition. Second, democracy increases uncertainty, as future governments may not necessarily continue policies and honor commitments introduced by the previous government. On the other hand, as emphasized by North $(1991,1993)$ and others, democracy ensures that property rights are guaranteed and is therefore a necessary precondition for sustained long-term growth. Anecdotal and survey evidence, especially from the former Soviet Union, seems to support this point (see Shleifer, 1998).

At first sight at least, democracy is seemingly associated with higher growth during transition. Table 1 reports values of a democracy index based on the Freedom House indices of political rights and civil liberties. 8 Countries that introduced wide-ranging democracy generally report higher growth. This pattern is unlikely to be due to reverse causality (faster growing countries being able to introduce greater democracy) because democratization largely preceded resumption of growth in post-communist countries.

Although the trade off between democracy and growth has been frequently alluded to in the transition literature and policy discussions, the effect of democracy on economic growth during transition has not been explicitly studied. Nevertheless, De Melo et al. (1996) and Dethier et al. (1999) observe that the extent of democracy among post-communist countries is positively correlated with the progress in economic liberalization (the correlation coefficient between annual values of the liberalization and democracy indices over 1990-98 is 0.66). They argue therefore that democracy facilitates economic liberalization and thus has a positive, albeit indirect, effect on growth (without considering the direct effect).

\footnotetext{
${ }^{8}$ The index reported in Table 1 is the average of the two indices, rescaled to take values between zero (no democracy) and unity (full democracy).
} 
Democracy appears to have a strong positive effect on growth when entered in a regression without controlling for the progress in liberalization (see Popov, 2000). However, the result is strikingly different when democracy is entered alongside liberalization, as shown in panel A of Table 3. The regressions control for the same variables included already in Table 2: the liberalization index, the distance from Western Europe, secondary school enrollment, the two war dummies, and initial GNP. Table 3 distinguishes between the marginal effect of democracy on growth (i.e. the effect after controlling for the progress in economic liberalization) reported in panel $\mathrm{A}$ and the total effect (i.e. accounting also for the indirect effect of democracy on growth through its effect on economic liberalization) in panel B.

\section{Insert Table 3 here.}

The marginal effect of democracy on growth turns out insignificant in the regressions spanning the entire period. Nevertheless, the effect appears negative and significant during the first part of transition, as reflected in the negative coefficient on an interaction term between the democracy index and a dummy for 1990-93 (column 2). This pattern is confirmed also in the separate regression for 1990-93, although only with a marginally significant coefficient (this can largely be attributed to the smaller sample size). Hence, after controlling for progress in economic liberalization, it appears that democracy hindered growth, at least during the early transition period. However, this does not necessarily imply that the overall effect of democracy on growth was also negative. As argued by De Melo et al. (1996) and Dethier et al. (1999), democracy may reinforce progress in economic liberalization and, because liberalization has a positive effect on growth, the total effect of democracy may in fact be positive. ${ }^{9}$ Panel $\mathrm{B}$ of Table 3 therefore investigates the overall effect of democracy. This is done by a two-step procedure. ${ }^{10}$ First, the liberalization index is regressed on the democracy index. This yields the following estimates (with t-statistics in parentheses):

$\begin{array}{lll}\text { 1990-98: } & \text { Liberalization }=0.185(5.42)+0.632(12.45) * \text { Democracy } & \left.\text { [Adj. } R^{2}: 0.759\right] \\ \text { 1990-93: } & \text { Liberalization }=-0.111(2.70)+0.956(15.34) * \text { Democracy } & \text { [Adj. } R^{2}: 0.662 \text { ] } \\ \text { 1994-98: } & \text { Liberalization }=0.393(11.06)+0.435(8.78) * \text { Democracy } & \left.\text { [Adj. } R^{2}: 0.752\right]\end{array}$

9 Dethier et al. (1999) stop short of testing for causality between liberalization and democracy. Nevertheless, a simple Granger causality test reported in the next section confirms that indeed democracy causes liberalization rather than the other way around.

${ }^{10}$ I am indebted to Sylviane Guillaumont for this suggestion. 
Second, the residuals from the above regressions are used as an explanatory variable, denoted residual liberalization, alongside the democracy index. Residual liberalization measures liberalization beyond the level that can be explained by democracy.

Applying this procedure, the total effect of democracy on growth (panel B of Table 3) appears positive and strongly significant. Nevertheless, the coefficient on the interaction term between the democracy index and the dummy for 1990-93 again indicates that the effect is less pronounced during the early period (this is also reflected in separate regressions for 199093 and 1994-98 reported in columns 10 and 11). Importantly, the effect of residual liberalization remains positive and mostly significant, i.e. liberalization beyond the level that is attributable to democracy is beneficial for growth.

In summary, democracy indeed has had a positive overall effect on growth during transition because of its positive impact on economic liberalization. However, democracy alone, when not accompanied by correspondingly far-reaching liberalization, had a negative marginal effect on growth during the early transition period (1990-93). The negative marginal effect can be ascribed to two factors (at least). First, democracy is associated with greater political uncertainty, as democratic governments are faced with political backlash in the wake of short-term adverse effects of the reforms. Such uncertainty may reduce the incentives for economic agents to engage in long-term profit-seeking activities. Second, governments facing elections may pursue short-term political aims or implement policies that constrain actions of the future government (see Chapter 2 in Roland, 2000) even if the outcome of such actions is detrimental to economic performance. Both factors become less important during the later phase of the transition, as economic and political developments consolidate.

\section{Determinants of Democracy}

The previous section treated democracy as exogenous, assuming the post-communist countries were free to choose any level of democracy. However, democratization itself is an outcome of political processes (one of them being elections, the topic of the next section), which, in turn, may be affected by the ongoing economic developments as well as initial conditions. Therefore, this section explores the underlying determinants of democratization in the post-communist countries. A standard finding on the relationship between democracy and economic performance is that democracy is positively correlated with economic development—as countries become more affluent, they also turn more democratic (see Lipset, 
1959; Helliwell, 1994; Barro, 1996, 1999; Londregan and Poole, 1996)—a finding referred to in Political Science as the Economic Development Thesis (Burkhart and Lewis-Beck, 1994). Accordingly, since the post-communist economies experienced dramatic deteriorations in standards of living, one should expect the initial democratization to be reversed (indeed, this is the prediction formulated by Barro, 1996, for Hungary).

To test this prediction, Table 4 relates the extent of democracy attained during 1994-98 to the progress in liberalization, democracy and the average growth rate, all pertaining to 199093. The regressions thus seek to determine the effect of economic performance as well as those of prior progress in economic liberalization and democratization on the subsequent extent of democracy. The focus is on democratization in the later transition period as the initial democratization was apparently largely exogenous (reflecting primarily the extent of popular discontent with communism and the ability of the former communists to retain power). As discussed above, after the initial democratization, the subsequent progress differed substantially, ranging from re-imposition of authoritarian regimes (as was the case in Belarus and much of Central Asia) to implanting democracy comparable to that in Western Europe. A question of particular interest is whether the countries that experienced more severe output fall responded by reversing the initial democratization-as implied by the economic development thesis.

\section{Insert Table 4 here.}

In contrast to the prediction stipulated by the economic development thesis, the effect of past growth on subsequent democracy turns out negative. In fact, the lagged average growth rate appears as the most significant determinant of subsequent democratization. The result is robust to omitting the liberalization and democracy indices from the regression. Moreover, regressions with contemporaneous growth rates yield insignificant coefficients on growth both for 1990-93 and 1994-98 (not reported).

To further test the robustness of this finding, column (5) reports regression results with the growth rate replaced by a residual growth rate, constructed as the residual from a regression relating growth during 1990-93 to contemporaneous liberalization (including a squared term), democracy, the distance from Western Europe, a dummy for military conflicts and the log of initial GNP (the results of this regression are reported in the Notes accompanying Table 4). This approach should eliminate the possibility of a bias stemming from the correlation between growth and the other explanatory variables included in Table 4 (see the discussion in sections 3 and 4). The coefficient estimated for residual growth thus measures the net effect of 
growth whereas the coefficients estimated for the remaining explanatory variables now measure their total contributions to the progress in democratization-including any indirect impact they may exert on democracy via their effect on growth. Nonetheless, the effect of growth on democracy obtained using this procedure remains negative and significant, and of essentially the same magnitude as before. Hence, it appears that the effect of growth on the subsequent democratization is indeed negative, i.e. the deeper is the initial output fall, the greater is the subsequent extent of democracy.

Though peculiar at first sight, this relationship may be due to the specific nature of the post-communist period. After the initial democratization (which, as discussed above, was largely exogenously determined), countries that experienced deeper output fall in turn may have experienced more dramatic political transitions, with the governments being replaced by more reform-minded ones. In contrast, countries that remained autocratic, but succeeded in avoiding an excessive output fall (for example Belarus and Uzbekistan), in turn stayed nondemocratic. Nevertheless, further research may be necessary to shed additional light on this perplexing result.

Finally, the regressions summarized in Table 4 suggest that both lagged democracy and liberalization enhance subsequent democracy. Yet, it was argued in the preceding section (in line with Dethier et al, 1999, and de Melo et al., 1996) that the causality runs from democracy to liberalization. This question deserves greater attention. A simple Granger-causality test reveals that indeed democracy causes liberalization rather than the other way around. When regressing annual observations of the democracy index on the liberalization index, and vice versa, the following results obtain 12 .

$$
\begin{array}{ll}
\mathrm{LI}_{\mathrm{t}}=0.108(8.12)+0.720(15.58) * \mathrm{LI}_{\mathrm{t}-1}+0.166(3.73) \mathrm{DI}_{\mathrm{t}-1} & \text { [adj. } \mathrm{R} 2=0.884] \\
\mathrm{DI}_{\mathrm{t}}=0.109(4.32)-0.068(-1.37) * \mathrm{LI}_{\mathrm{t}-1}+0.921(21.89) \mathrm{DI}_{\mathrm{t}-1} & \text { [adj. } \mathrm{R} 2=0.771]
\end{array}
$$

where $\mathrm{LI}_{\mathrm{t}}$ and $\mathrm{DI}_{\mathrm{t}}$ stand for liberalization and democracy indices, respectively. The results clearly show that whereas the lagged value of the democracy index is significant as a determinant of subsequent liberalization, the lagged value of the liberalization index does not

\footnotetext{
${ }^{11}$ Nevertheless, the opposite result is obtained in analogous regressions with annual rather than averaged data and one-year lags-growth appears to have a positive lagged effect on democracy (results are available on request). However, the magnitude of the effect is much smaller (one tenth of that reported in Table 4, in absolute value) and it is only significant in a regression spanning the entire transition period (1990-98). In separate regressions for 1990-93 and 1994-98, it turns out insignificant (and actually negative in the former).

${ }^{12}$ Heteroskedasticity t-statistics are in parentheses. The regressions are estimated with 224 observations, i.e. 9 years and 25 countries, with one observation missing (Macedonia in 1990). Because of the short length of the series, only one lag is included.
} 
cause subsequent democracy. The results are analogous when additional variables (initial percapita GNP, years under communism, military conflict dummy and quadratic time trend) are included (not reported).

\section{Economic Performance and Political Support for Reforms}

After studying the inter-relationships between economic performance, liberalization and democratization, I now turn to the ultimate mechanism determining policy choices: elections. Elections are the major feedback channel through which voters express their displeasure about past and current policies and, by choosing the government, select policies to be implemented in the future (see Nannestad and Paldam, 1994, for an extensive survey of the recent literature).

Economic reforms were associated with a substantial worsening of the standard of living for large segments of the transition economies' populations, at least in the short term. In turn, the support for radical economic reforms collapsed dramatically shortly after the onset of the reforms. Fidrmuc $(2000 \mathrm{a}, \mathrm{b})$ shows that the intensity of the political backlash against reforms reflects the balance between favorable and adverse effects of the reforms. A good example of this relationship is the Czech Republic, where the pro-reform parties remained in power for as long as unemployment remained low.

The relationship between economic performance and the support for reforms has been explored mainly theoretically so far (see, for example, Rodrik, 1995). Empirical analysis has been scarce up to date, primarily because of the lack of appropriate data. Recent empirical work includes Warner (1997), Brainerd (1999), Hayo (1999) and Fidrmuc (2000a,b). The approach utilized in the present paper is similar to that of Fidrmuc (2000b), but instead of using regional data, the analysis is based on a cross section of 17 elections in seven countries of Central and South-Eastern Europe: the Czech Republic, Slovakia, Hungary, Poland, Romania, Bulgaria, and Slovenia. This subset of countries was chosen because they are all at least moderately democratic (any analysis of electoral outcomes would be meaningless in non-democratic countries, which then excludes most of the former Soviet Republics), data for them are relatively easy to come by, and classification of parties according to their political orientation is relatively straightforward than is the case with other countries.

Table 5 presents the results. The dependent variable is the share of votes received in each election by parties categorized along two dimensions: their political orientation (pro-reform parties, and left wing/nationalist parties), and incumbency (cf. Fidrmuc, 2000b). The election 
results are regressed on variables reflecting economic performance: unemployment rate, growth rate, index of output relative to the level attained in 1989 and the inflation rate. In addition, the regressions reported in the lower part of Table 5 include also the liberalization and democracy indices. All variables pertain to the election year. ${ }^{13}$ The regressions were estimated by OLS with heteroskedasticity robust standard errors. Using the logit transformation for the dependent variable yielded virtually identical results. 4

\section{Insert Table 5 here.}

The results for economic-performance variables reveal a pattern similar to the findings of Fidrmuc (2000a,b). Regressions where parties are classified according to their political orientation yield very high explanatory power (with adjusted $\mathrm{R}^{2}$ of 0.6 or higher). In contrast, regressions with parties classified according to incumbency yield adjusted $\mathrm{R}^{2}$ of only 0.3-0.4. Hence, the categorization of parties according to their political orientation is apparently better suited for the analysis of factors underlying voting behavior in the transition countries. The results suggest that economic performance has strong bearing on electoral outcomes. Unemployment reduces the support for pro-reform parties, and increases the support for left wing and nationalist parties. One percentage point of unemployment transforms into a gain of nearly two percentage points for the left-wing and nationalist parties, and a corresponding loss for the reformers. Economic growth shows positive effect on the votes for pro-reform parties and negative effect on the votes for left wing and nationalist parties (however, both effects are only (marginally) significant in the regressions that include also the indices of liberalization and democracy). Similarly, the higher the level of real output compared to 1989, the greater the support for pro-reform parties and the lower the support for left-wing and nationalist parties.

The effect of inflation is somewhat surprising. Apparently, inflation increases support for the pro-reform parties and reduces support for the left wing and nationalist parties. A plausible explanation is that the support for pro-reform parties rises when inflation is high, as the voters' turn to the pro-reform parties with a record of reigning in inflation.

The magnitude of these effects is economically (and politically) significant. Pro-reform parties lose on average one percentage point in support for each half a percentage point increase in the unemployment rate or a reduction in the annual growth rate by three

\footnotetext{
${ }^{13}$ Choosing the year prior to the election delivered worse quality of statistical fit.

14 The logit transformation corresponds to converting the dependent variable into the following form: $\log [\mathrm{V} /(1-\mathrm{V})]$, where $\mathrm{V}$ is the vote share for a particular party (cf. Greene, 1997, p. 895).
} 
percentage points. Left wing and nationalist parties gain correspondingly. Hence, an increase in the unemployment rate by 4 percentage points-as was for example the case in the Czech Republic between elections in 1996 and 1998 - transforms into a vote loss of 8 percentage points for the reformers. On the other hand, every 100 percentage-point increase in the inflation rate expands the votes for the pro-reform parties by four percentage points.

Controlling for the effects of liberalization and democracy on electoral outcomes improves the quality of statistical fit (except for the regression according to incumbency). The results paint a somewhat peculiar pattern though: the support for pro-reform parties is inversely related to liberalization but positively related to democracy. Both effects are economically significant. Importantly, the vote gain from democratization is greater that the vote loss from economic liberalization. An increase in the value of the democracy index by 0.1 (recall that both indices range between 0 and 1) transforms into a gain of four percentage points for the pro-reform parties. The same increase in the liberalization index reduces the vote for the pro-reform parties by 3.5 percentage points. This empirical finding goes counter the argument put forward by some analysts, who argue that the governments implementing wide-ranging reforms need to be shielded from political backlash caused by adverse shortterm effects of the reforms. On the contrary, democracy-minded reformers are apparently rewarded by voters (which, however, does not make them immune to political backlash, which can still occur in response to the adverse effects of the reforms). The effect of liberalization and democracy on the support for left wing and nationalist parties is positive, but essentially insignificant (perhaps because of the correlation between the two indices, as the effect turns out significant when only one index is included).

Greater liberalization brings about lower support for the pro-reform parties, even after controlling for the economic effects of the reforms-unemployment, growth, output fall and inflation. Hence, adverse effects of economic reforms apparently go beyond what is accounted for by basic economic statistics. A plausible interpretation is that the progress in liberalization is positively correlated with the fraction of the electorate affected by transitionrelated redistribution of rents and relative socio-economic deprivation. This is likely to be the case at least in the short term, whereas the favorable effects of the reform generally accrue later.

Regression with parties classified according to incumbency result in worse statistical fit than regressions according to parties' political orientation. This is analogous to the findings reported by Fidrmuc (2000b). Only unemployment rate and output level are significant and 
have the expected signs. Growth is insignificant and even has the wrong sing. Finally, greater democracy makes the government more likely to be toppled in an election (although the effect is barely marginally significant).

The stronger results when parties are classified according to their political orientation rather than incumbency suggest that the patterns of political support are rather stable over time and independent of the parties' incumbency status. Hence, voters' support is associated with the political orientation of individual parties (and thus the policies that the parties are expected to deliver) rather than the past performance of the party or coalition currently in office. The former pattern of voters' support_clientelistic/forward-looking voting (Nannestad and Paldam, 1994) —implies that voters tend to associate themselves with a party that best represents their interests. It contrasts with the latter pattern-retrospective voting-which is the pattern typically observed in developed countries, where voters punish the government for bad economic performance by voting for the opposition.

\section{Conclusions}

The present paper documents and analyzes several important inter-relations between economics and politics during the post-communist transitions in Central and Eastern Europe and the former Soviet Union. The results can be summarized as follows: (1) Liberalization has a strong positive effect on growth during transition. This holds also when controlling for the possible endogeneity of liberalization in growth. (2) Democracy encourages liberalization, countries which introduced greater democracy subsequently progress further in economic liberalization too. (3) Because of its reinforcing effect on liberalization, democracy has a positive overall impact on growth. Nevertheless, the marginal effect of democracy (after controlling for progress in economic liberalization) was negative during the early part of transition. (4) The progress in democratization in turn depends on past economic performance in a surprising manner-the relationship between past growth and subsequent democracy appears negative. Further research may be necessary to illuminate this result. (5) Economic performance is an important determinant of electoral outcomes and, in particular, of support for reforms. Support for parties associated with reforms falls with unemployment and increases with growth, output level relative to 1989 and, somewhat surprisingly, inflation.

Hence, there are merits to simultaneous democratization and liberalization-democracy facilitates liberalization, which, in turn, improves growth performance. This is an important 
lesson for those transition economies, that remain autocratic (e.g. China, Belarus, Serbia—at least until recently), those that may now be reversing the initial democratization (e.g. Russia under president Putin) in the hope of improving economic performance, as well as other nondemocratic developing countries. Yet, democratization alone is not the key to growth, it is through its positive impact on economic liberalization that it improves growth performance. A centrally planned democracy would be even less conducive to growth than an autocratic market economy.

Finally, economic performance is an important determinant of political processes, and in particular electoral outcome. Hence, while radical reforms generally give rise to better economic performance in the long term, the need to sustain sufficient political support for their continuation requires careful balancing of costs and benefits of reforms and in particular their effects on different socio-economic groups.

\section{References}

Alesina, Alberto, and Allan Drazen (1991), “Why Are Stabilizations Delayed?" American Economic Review 81 (5), 1170-1188.

Åslund, Anders, Peter Boone and Simon Johnson (1996), "How to Stabilize: Lessons from Post-communist Countries,” Brookings Papers on Economic Activity 1, 217-291.

Barro, Robert (1991), "Economic Growth in a Cross Section of Countries," Quarterly Journal of Economics 106, 407-443.

Barro, Robert J. (1996), “Democracy and Growth,” Journal of Economic Growth 1 (1), 1-27.

Berg, Andrew, Eduardo Borensztein, Ratna Sahay, and Jeromin Zettelmeyer (1999), The Evolution of Output in Transition Economies: Explaining the Differences, IMF Working Paper WP/99/73.

Berglund, Sten, Hellén Tomas, and Frank H. Aarebrot (1998), “The Handbook of Political Change in Eastern Europe," Edward Elgar, Cheltenham, UK.

Blanchard, Olivier and Michael Kremer (1997), "Disorganization," Quarterly Journal of Economics (November), 1091-1126.

Brainerd, Elizabeth (1999), "Winners and Losers in Russia’s Economic Transition," American Economic Review 88, 1094-1116.

Burkhart, Ross E. and Michael S. Lewis-Beck (1994), "Comparative Democracy: The Economic Development Thesis." American Political Science Review 88, 903-910.

Calvo, Guillermo A., and Fabrizio Coricelli (1993), "Output Collapse in Eastern Europe: The Role of Credit," IMF Staff Papers 40 (1).

Campos, Nauro (1999), Back to the Future: The Growth Prospects of Transition Economies Reconsidered, William Davidson Institute Working Paper No. 229, Ann Arbor, MI. 
De Melo, Martha, Cevdet Denizer, and Alan Gelb (1996), "Patterns of Transition from Plan to Market," World Bank Economic Review 10 (3), 397-424.

De Melo, Martha, Cevdet Denizer, Alan Gelb and Stoyan Tenev (1997), "Circumstance and Choice: The Role of Initial Conditions and Policies in Transition Economies," World Bank Policy Research Paper, The World Bank.

Denizer, Cevdet (1997), Stabilization, Adjustment and Growth Prospects in Transition Economies, Policy Research Working Paper No. 1855, The World Bank, Washington, DC.

Dethier, Jean-Jacques, Hafez Ghanem and Edda Zoli (1999), "Does Democracy Facilitate the Economic Transition? An Empirical Study of Central and Eastern Europe and the Former Soviet Union," Journal for Institutional Innovation, Development and Transition (IB Review) 3, 15-30. Also available as Policy Research Working Paper No. 2194, The World Bank.

Fernandez, Raquel and Dani Rodrik (1991), "Resistance of Reform: Status Quo Bias in the Presence of Individual-Specific Uncertainty," American Economic Review 81, 11461155.

Fidrmuc, Jan (2000a), "Political Support for Reforms: Economics of Voting in Transition Countries," European Economic Review 44 (8), August 2000, 1491-1513.

Fidrmuc, Jan (2000b), "Economics of Voting in Post-communist Countries," Electoral Studies 19 (2/3), Special issue: Economics and Elections, June/September 2000, 199-217.

Fischer, Stanley; Sahay, Ratna; Vegh, Carlos A (1996), "Stabilization and Growth in Transition Economies: The Early Experience," Journal of Economic Perspectives 10 (2), 45-66.

Fischer, Stanley; Sahay, Ratna; Vegh, Carlos A (1998a), "From Transition to Market: Evidence and Growth Prospects," IMF Working Paper WP/98/52.

Fischer, Stanley; Sahay, Ratna; Vegh, Carlos A (1998b), "How Far is Eastern Europe from Brussels?" IMF Working Paper WP/98/53.

Fischer, Stanley, and Sahay, Ratna (2000), “The Transition after Ten Years," IMF Working Paper WP/00/30, February 2000.

Greene, William H. (1997), Econometric Analysis, Prentice Hall International, third edition.

Hallagan, William, and Jun Zhang (1999), Starting Position, Reform Speed, and Economic Outcomes in Transition Economies, conference paper, $4^{\text {th }}$ Annual International Conference on Transition Economics, Beijing.

Havrylyshyn, Oleh, Ivailo Izvorski, and Ron van Rooden (1998), "Recovery and Growth in Transition Economies 1990-97: A Stylized Regression Analysis," IMF Working Paper WP/98/141.

Hayo, Bernd (1999), "Determinants of Public Support for Market Reforms in Eastern Europe," Center for European Integration Studies, University of Bonn, mimeo.

Helliwell, John F. (1994), "Empirical Linkages between Democracy and Economic Growth," British Journal of Political Science 24, 225-248.

Heybey, Berta, and Peter Murrel (1999), “The Relationship between Economic Growth and the Speed of Liberalization During Transition," Journal of Policy Reform 3 (2), 121-137. 
Hillman, Arye L. and Heinrich W. Ursprung (2000), "Political Culture and Economic Decline," European Journal of Political Economy 16, 189-213.

Krueger, Gary, and Marek Ciolko (1998), "A Note on Initial Conditions and Liberalization during Transition," Journal of Comparative Economics 26, 718-734.

Levine, Ross and David Renelt (1992), "A Sensitivity Analysis of Cross-Country Growth Regressions," American Economic Review 82 (4), 942-963.

Lipset, S.M. (1959), "Some Social Requisites of Democracy: Economic Development and Political Legitimacy,” American Political Science Review 53, 69-105.

Londregan, John B. and Keith T. Poole (1996), "Does High Income Promote Democracy?" World Politics 49 (October), 1-30.

Minier, Jenny A. (1998), "Democracy and Growth: Alternative Approaches," Journal of Economic Growth 3 (September), 241-266.

Nannestad, Peter and Martin Paldam (1994), "The VP-Function: A Survey of Literature on Vote and Popularity Functions after 25 Years," Public Choice 79, 213-245.

North, Douglass C. (1991), Institution, Institutional Change and Economic Performance, Cambridge University Press, Cambridge, UK.

North, Douglass C. (1993), "The Paradox of the West," Economics Working Paper Archive, Washington University-St. Louis, Missouri.

Olson, Mancur (2000), Power and Prosperity: Outgrowing Communist and Capitalist Dictatorships, Basic Books, New York, NY.

Popov, Vladimir (2000), "Shock Therapy Versus Gradualism: The End of the Debate (Explaining the Magnitude of Transformational Recession)," Comparative Economic Studies 42 (1), 1-57.

Przeworski, Adam, and Fernando Limongi (1993), "Political Regimes and Economic Growth," Journal of Economic Perspectives 7 (3), 51-69.

Rodrik, Dani (1995), "The Dynamics of Political Support for Reforms in Economies in Transition," Journal of the Japanese and International Economies 9 (4), 403-425.

Rodrik, Dani (1996), "Understanding Economic Policy Reform," Journal of Economic Literature XXXIV (March), 9-41.

Rodrik, Dani (1999), “Democracies Pay Higher Wages.” Quarterly Journal of Economics 104 (3), 707-737.

Rodrik, Dani (2000), Institutions For High-Quality Growth: What They Are And How To Acquire Them. CEPR Discussion Paper No. 2370. Centre for Economic Policy Research, London.

Roland, Gérard, and Thierry Verdier (1999), "Transition and the Output Fall," Economics of Transition 7 (1), 1-28.

Shleifer, Andrei (1998), "Government in Transition," European Economic Review 41 (3-5), 385-410.

Sachs, Jeffrey (1996), "The Transition at Mid Decade," American Economic Review: Papers and Proceedings 86 (2), 128-133.

Selowsky, Marcelo and Ricardo Martin (1997), "Policy Performance and Output Growth in 
the Transition Economies," American Economic Review (Papers and Proceedings) 87 (2), 349-353.

Warner, Andrew (1997), “Is Economic Reform Popular at the Polls: Russia 1995?” Harvard Institute for International Development, mimeo.

Wolff, Holger C. (1999), Transition Strategies: Choices and Outcomes, Princeton Studies in International Finance No. 85 (June), Department of Economics, Princeton University, Princeton, NJ. 
Table 1 Countries in Transition: Indicators of Economic Performance, Liberalization, Democracy, and Initial Conditions

\begin{tabular}{|c|c|c|c|c|c|c|c|c|c|c|c|c|c|c|}
\hline & $\begin{array}{c}\text { Avg. } \\
\text { Growth }\end{array}$ & $\begin{array}{c}\text { Avg. } \\
\text { Growth }\end{array}$ & $\begin{array}{c}\text { Avg. } \\
\text { Growth }\end{array}$ & $\begin{array}{l}\text { Output } \\
\text { Fall }\end{array}$ & $\begin{array}{c}\text { Output } \\
\text { Recovery }\end{array}$ & $\begin{array}{l}\text { GNP p.c. } \\
\text { [USD] }\end{array}$ & $\begin{array}{l}\text { Liberal. } \\
\text { Index }\end{array}$ & $\begin{array}{l}\text { Liberal. } \\
\text { Index }\end{array}$ & $\begin{array}{l}\text { Democr. } \\
\text { Index }\end{array}$ & $\begin{array}{l}\text { Democr. } \\
\text { Index }\end{array}$ & $\begin{array}{l}\text { Dist. Fr. } \\
\text { Brussels }\end{array}$ & $\begin{array}{l}\text { Sec.Sch. } \\
\text { Enrollm }\end{array}$ & $\begin{array}{l}\text { Pop. } \\
\text { Growth }\end{array}$ & $\begin{array}{l}\text { Pop. } \\
\text { Growth }\end{array}$ \\
\hline & $1990-98$ & $1990-93$ & 1994-98 & $1990-98$ & $1990-98$ & 1989 & & $1994-98$ & $1990-93$ & $1994-98$ & & & $1990-93$ & \\
\hline Albania & -0.77 & -8.83 & 5.68 & 60.38 & 26.02 & 1400 & 0.40 & 0.63 & 0.479 & 0.517 & 2427 & 79 & -0.40 & 0.98 \\
\hline Armenia & -7.06 & -22.98 & 5.68 & 31.00 & 9.84 & 5530 & 0.25 & 0.57 & 0.479 & 0.483 & 4167 & 85 & 1.73 & 0.33 \\
\hline Azerbaijan & -8.04 & -14.53 & -2.86 & 36.96 & 6.65 & 4620 & 0.16 & 0.45 & 0.313 & 0.250 & 4321 & 83 & 1.41 & 1.08 \\
\hline Belarus & -2.43 & -5.35 & -0.10 & 62.69 & 15.06 & 7010 & 0.17 & 0.41 & 0.479 & 0.250 & 1881 & 92 & 0.31 & -0.23 \\
\hline Bulgaria & -4.37 & -7.40 & -1.94 & 63.69 & 2.23 & 5000 & 0.58 & 0.63 & 0.729 & 0.783 & 2175 & 71 & -1.17 & -0.51 \\
\hline Croatia & -2.43 & -12.35 & 5.50 & 58.58 & 17.94 & 6171 & 0.69 & 0.75 & 0.500 & 0.500 & 1399 & 80 & 0.06 & -1.20 \\
\hline Czech Rep. & -0.36 & -3.65 & 2.28 & 85.24 & 10.54 & 8600 & 0.68 & 0.83 & 0.854 & 0.917 & 913 & 89 & -0.07 & -0.07 \\
\hline Estonia & -2.68 & -11.23 & 4.16 & 60.76 & 14.98 & 8900 & 0.49 & 0.80 & 0.646 & 0.867 & 2508 & 92 & -0.99 & -0.91 \\
\hline Georgia & -9.76 & -25.80 & 3.08 & 25.38 & 7.42 & 5590 & 0.23 & 0.55 & 0.354 & 0.483 & 4193 & 82 & -0.04 & 0.01 \\
\hline Hungary & -0.41 & -4.78 & 3.08 & 81.89 & 13.36 & 6810 & 0.73 & 0.84 & 0.854 & 0.917 & 1412 & 81 & -0.25 & -0.35 \\
\hline Kazakhstan & -5.14 & -6.38 & -4.16 & 61.26 & 0.00 & 5130 & 0.22 & 0.58 & 0.375 & 0.250 & $6000^{\mathrm{e}}$ & 90 & 0.35 & -1.10 \\
\hline Kyrgyzstan & -4.84 & -9.25 & -1.32 & 50.39 & 9.99 & 3180 & 0.25 & 0.70 & 0.500 & 0.483 & $6000^{e}$ & 88 & 0.87 & 0.94 \\
\hline Latvia & -4.67 & -14.33 & 3.06 & 50.97 & 8.27 & 8590 & 0.40 & 0.72 & 0.625 & 0.850 & 2197 & 92 & -0.93 & -1.09 \\
\hline Lithuania & -4.08 & -12.05 & 2.30 & 53.47 & 12.12 & 6430 & 0.45 & 0.74 & 0.688 & 0.900 & 1785 & 78 & 0.26 & -0.15 \\
\hline Macedonia & -5.32 & -13.05 & 0.86 & 55.11 & 4.09 & 3394 & 0.68 & 0.67 & 0.563 & 0.600 & 2225 & 80 & -0.83 & 0.78 \\
\hline Moldova & -10.98 & -12.33 & -9.90 & 32.36 & 0.00 & 4670 & 0.26 & 0.62 & 0.375 & 0.567 & 2233 & 81 & -0.01 & -0.23 \\
\hline Poland & 1.98 & -3.05 & 6.00 & 82.21 & 34.94 & 5150 & 0.76 & 0.81 & 0.833 & 0.900 & 1338 & 83 & 0.32 & 0.11 \\
\hline Romania & -2.77 & -6.45 & 0.18 & 74.99 & 1.10 & 3470 & 0.40 & 0.65 & 0.396 & 0.717 & 2234 & 80 & -0.43 & -0.22 \\
\hline Russia & -6.14 & -7.80 & -4.82 & 55.89 & 0.00 & 7720 & 0.31 & 0.67 & 0.563 & 0.567 & 2607 & 92 & 0.13 & -0.22 \\
\hline Slovakia & 0.22 & -6.83 & 5.86 & 74.97 & 24.67 & 7600 & 0.66 & 0.79 & 0.771 & 0.733 & 1223 & 96 & 0.13 & 0.25 \\
\hline Slovenia & 0.57 & -4.08 & 4.28 & 82.04 & 21.95 & 9200 & 0.73 & 0.79 & 0.729 & 0.917 & 1352 & 80 & -0.41 & 0.15 \\
\hline Tajikistan & -8.61 & -12.18 & -5.76 & 39.19 & 2.78 & 3010 & 0.15 & 0.41 & 0.313 & 0.067 & $6000^{e}$ & 73 & 2.13 & 1.62 \\
\hline Turkmenistan & -8.32 & -4.50 & -11.38 & 41.99 & 1.76 & 4230 & 0.09 & 0.31 & 0.188 & 0.000 & $6000^{e}$ & 70 & 4.64 & 1.82 \\
\hline Ukraine & -10.29 & -10.63 & -10.02 & 36.76 & 0.00 & 5680 & 0.13 & 0.52 & 0.563 & 0.583 & 2215 & 80 & 0.20 & -0.74 \\
\hline Uzbekistan & -1.12 & -3.08 & 0.44 & 83.36 & 6.23 & 2740 & 0.16 & 0.54 & 0.208 & 0.050 & $6000^{e}$ & 94 & 2.18 & 1.83 \\
\hline Average & -4.31 & -9.71 & 0.01 & 57.66 & 10.08 & 5432 & 0.401 & 0.640 & 0.535 & 0.566 & 2992 & 83.64 & 0.37 & 0.12 \\
\hline
\end{tabular}

Sources: EBRD Transition Report (various issues), de Melo et al. (1996, 1997), Freedom House, World Bank World Development Report 1996, Shell Route Planner.

Notes: Output Fall is the lowest level of GDP attained between 1990 and 1998, with 1989=100. Output Recovery is the cumulative increase in GDP (in percent) since reaching the lowest level. GNP per capita in 1989 is in US\$ at purchasing power parity as reported by de Melo et al. (1996). Liberalization Index is unweighted mean of the indices constructed by de Melo et al., as extended by Havrylyshyn et al. (1998). The index ranges between zero (no liberalization) and one (complete liberalization). Democracy Index is average of political rights and civil liberties (reported by the Freedom House), respectively, ranging between zero (no democracy) and one (complete democracy). Distance from Brussels is road distances in kilometers. Distances indicated with ${ }^{\mathrm{e}}$ are estimates rather than actual distances. School enrollment is according to Denizer (1997) and relates to early 1990s. Population growth is from Campos (1999). 
Table 2A Economic Liberalization, Initial Conditions and Growth

\begin{tabular}{|c|c|c|c|c|c|c|c|c|c|c|c|c|c|c|c|c|}
\hline $\begin{array}{l}\text { Period: } \\
\text { Growth Rate of: }\end{array}$ & $\begin{array}{c}1990-98 \\
\text { GDPpc } \\
(1)\end{array}$ & t-stat 1 & $\begin{array}{c}\text { 1990-98 } \\
\text { GDPpc } \\
(2)\end{array}$ & t-stat & $\begin{array}{c}\text { 1990-98 } \\
\text { GDPpc } \\
(3)\end{array}$ & t-stat & $\begin{array}{c}1990-98 \\
\text { GDP } \\
(4)\end{array}$ & & $\begin{array}{c}\text { 1990-93 } \\
\text { GDPpc } \\
(5)\end{array}$ & t-stat & $\begin{array}{c}\text { 1990-93 } \\
\text { GDPpc } \\
(6)\end{array}$ & t-stat & $\begin{array}{c}\text { 1994-98 } \\
\text { GDPpc } \\
(7)\end{array}$ & t-stat & $\begin{array}{c}\text { 1994-98 } \\
\text { GDPpc } \\
(8)\end{array}$ & t-stat \\
\hline Constant & -7.438 & -0.68 & -2.335 & -0.21 & 11.409 & 1.11 & 18.264 & 1.64 & 1.853 & 0.14 & 16.048 & 1.46 & -15.582 & -0.88 & -4.777 & -0.22 \\
\hline Dummy 1994-98 & 4.160 & 2.92 & -8.479 & -1.64 & 3.937 & 3.937 & 3.926 & 2.85 & & & & & & & & \\
\hline Liberalization Index & 12.941 & 4.08 & 8.752 & 2.57 & -41.252 & -4.75 & -51.148 & -5.44 & 12.467 & 2.83 & -40.539 & -2.98 & 22.675 & 3.13 & -5.222 & -0.14 \\
\hline Liberalization Squared & & & & & 56.998 & 5.84 & 66.337 & 6.40 & & & 58.712 & 4.09 & & & 23.339 & 0.72 \\
\hline Liberalization 1994-98 & & & 20.657 & 3.12 & & & & & & & & & & & & \\
\hline Dist. fr. Brussels [ths km] & -0.356 & -0.83 & -0.145 & -0.30 & -0.427 & -1.16 & -0.194 & -0.51 & 0.528 & 0.91 & 0.037 & 0.08 & -0.796 & -1.47 & -0.837 & -1.63 \\
\hline Sec. School Enrollment & 0.1389 & 1.57 & 0.097 & 1.39 & 0.175 & 2.89 & 0.164 & 2.79 & 0.005 & 0.06 & 0.088 & 1.36 & 0.225 & 2.73 & 0.251 & 2.53 \\
\hline War Dummy & -8.404 & -4.02 & -9.011 & -4.49 & -9.346 & -5.80 & -9.529 & -5.73 & -9.831 & -5.31 & -10.037 & -6.71 & & & & \\
\hline War Dummy (lagged) & 2.865 & 1.55 & 4.056 & 2.44 & 4.725 & 2.65 & 4.981 & 2.93 & & & & & 4.567 & 2.92 & 4.834 & 2.82 \\
\hline 1989 GNP p.c. $[\log$, ths $\$]$ & -1.908 & -1.47 & -1.957 & -1.61 & -3.275 & -3.00 & -3.779 & -3.11 & -1.930 & -1.25 & -3.183 & -2.93 & -1.939 & -1.00 & -2.527 & -1.17 \\
\hline $\operatorname{Adj} . R^{2}$ & 0.705 & & 0.757 & & 0.802 & & 0.793 & & 0.606 & & 0.735 & & 0.546 & & 0.530 & \\
\hline Joint Sign. Liberalization & & & & & 0.000 & & 0.000 & & & & 0.000 & & & & 0.003 & \\
\hline Number of observations & 50 & & 50 & & 50 & & 50 & & 25 & & 25 & & 25 & & 25 & \\
\hline Min/Max effect at: & & & & & 0.36 & & 0.39 & & & & 0.35 & & & & 0.11 & \\
\hline
\end{tabular}

Notes: Estimated by OLS with heteroskedasticity robust t-statistics, for the 25 countries included in Table 1 . Dependent variable is the growth rate of GDP per capita (GDPpc), or the growth rate of GDP. Columns (1) through (4) are estimated with observations for 1990-93 and 1994-98 pooled together. The liberalization index is the average annual liberalization index over the respective period, as constructed by de Melo et al. (1996) and extended by Havrylyshyn et al. (1998). Liberalization 1994-98 is an interaction term between the liberalization index and the dummy for 1994-98. The conflict dummy equals one for Croatia, Macedonia, Armenia, Azerbaijan, Georgia and Tajikistan. The initial per capita GNP is in purchasing power parity terms, in US dollars. The distance from Brussels for Kazakhstan, Kyrgyzstan, Tajikistan, Turkmenistan and Uzbekistan is estimated as $6,000 \mathrm{~km}$. Secondary school enrolment is according to Denizer (1997), in percent. Joint Significance Liberalization is the joint significance level of the liberalization index and its squared value. Minimum/Maximum effects refer to the level where the effect of liberalization reaches its minimum or maximum in the non-linear specification. 
Table 2B Economic Liberalization, Initial Conditions and Growth:

Liberalization Estimated with Instrumental Variables

\begin{tabular}{|c|c|c|c|c|c|c|c|c|c|c|c|c|}
\hline $\begin{array}{l}\text { Period: } \\
\text { Growth Rate of: }\end{array}$ & $\begin{array}{c}\text { 1990-98 } \\
\text { GDPpc } \\
(9)\end{array}$ & t-stat & $\begin{array}{c}\text { 1990-93 } \\
\text { GDPpc } \\
(10)\end{array}$ & t-stat & $\begin{array}{c}\text { 1994-98 } \\
\text { GDPpc } \\
(11)\end{array}$ & t-stat & $\begin{array}{c}\text { 1990-98 } \\
\text { GDPpc } \\
(12)\end{array}$ & t-stat & $\begin{array}{c}\text { 1990-93 } \\
\text { GDPpc } \\
(13)\end{array}$ & t-stat & $\begin{array}{c}\text { 1994-98 } \\
\text { GDPpc } \\
(14)\end{array}$ & t-stat \\
\hline Constant & 6.427 & 0.61 & 19.632 & 1.62 & -21.395 & -1.23 & 5.339 & 0.47 & 17.208 & 1.30 & -25.186 & -1.46 \\
\hline Dummy 1994-98 & 1.768 & 1.18 & & & & & 2.026 & 1.48 & & & & \\
\hline Liberalization Index & -29.365 & -2.87 & -52.121 & -2.63 & 28.103 & 3.79 & -28.193 & -2.94 & -36.682 & -2.07 & 34.092 & 4.95 \\
\hline Liberalization Squared & 48.758 & 4.45 & 74.249 & 3.66 & & & 48.288 & 5.06 & 57.587 & 3.22 & & \\
\hline Dist. fr. Brussels [ths km] & -0.021 & -0.05 & -0.112 & -0.20 & -0.263 & -0.45 & -0.058 & -0.15 & -0.066 & -0.11 & -0.074 & -0.15 \\
\hline Sec. School Enrollment & 0.173 & 3.08 & 0.083 & 1.49 & 0.256 & 3.62 & 0.230 & 3.49 & 0.071 & 1.22 & 0.390 & 5.63 \\
\hline War Dummy & -9.518 & -5.58 & -10.218 & -6.60 & & & -9.180 & -5.26 & -9.963 & -6.11 & & \\
\hline War Dummy (lagged) & 4.978 & 2.65 & & & 5.079 & 3.03 & 4.207 & 2.12 & & & 4.769 & 2.53 \\
\hline 1989 GNP p.c. $[\log$, ths $\$]$ & -3.082 & -2.75 & -3.222 & -2.81 & -2.196 & -1.13 & -3.562 & -2.80 & -3.192 & -2.42 & -3.588 & -1.73 \\
\hline Adj. $R^{2}$ & 0.800 & & 0.723 & & 0.576 & & 0.782 & & 0.692 & & 0.549 & \\
\hline Joint Sign. Liberalization & 0.000 & & 0.000 & & & & 0.000 & & 0.000 & & & \\
\hline Number of observations & 50 & & 25 & & 25 & & 50 & & 25 & & 25 & \\
\hline Min/Max effect at: & 0.30 & & 0.35 & & & & 0.29 & & 0.32 & & & \\
\hline
\end{tabular}

Notes: Estimated by OLS with heteroskedasticity robust t-statistics, for the 25 countries included in Table 1. See also Notes to Table 2 A. Joint Significance Liberalization is the joint significance level of the liberalization index and its squared value. Minimum/Maximum effects refer to the level where the effect of liberalization reaches its minimum or maximum in the non-linear specification.

The liberalization index has been instrumented by its lagged value (columns 9-11) or its initial value as of 1989 (columns 12-14), initial GNP, years under communism, conflict dummy, and quadratic time trend (using annual observations for 1990-98). The first-stage regressions (with heteroskedasticity-robust t-statistics in parentheses) are:

Columns 9-11:

$\mathrm{LI}_{\mathrm{t}}=0.343(5.72)+0.607(7.85) \mathrm{LI}_{\mathrm{t}-1}+0.010(2.53) \mathrm{GNP}-0.004(4.43)$ YrsCom - $0.014(0.93) \mathrm{War}+0.053(3.63) \mathrm{t}-0.006(4.32) \mathrm{t}^{2} \quad\left[a d j u s t e d \mathrm{R}^{2}=0.875\right]$

Columns 12-14:

$\mathrm{LI}_{\mathrm{t}}=0.514(9.29)+0.151(3.15) \mathrm{LI}_{1989}+0.024(6.54) \mathrm{GNP}-0.008(11.08)$ YrsCom $-0.012(0.74) \mathrm{War}+0.168(19.05) \mathrm{t}-0.015(13.82) \mathrm{t}^{2} \quad$ adjusted $\left.\mathrm{R}^{2}=0.813\right]$

where $L I$ stands for the annual liberalization index, $L I_{1989}$ is the value of this index attained in 1989, GNP is the initial GNP per capita, YrsCom is the number of years the country spent under communism, War is the conflict dummy and $t$ is transition-time trend set to zero for years preceding the onset of transition. Transition time is defined following Fischer and Sahay (2000, Figure 1). 
Table 3A Democracy and Growth: Marginal Effect

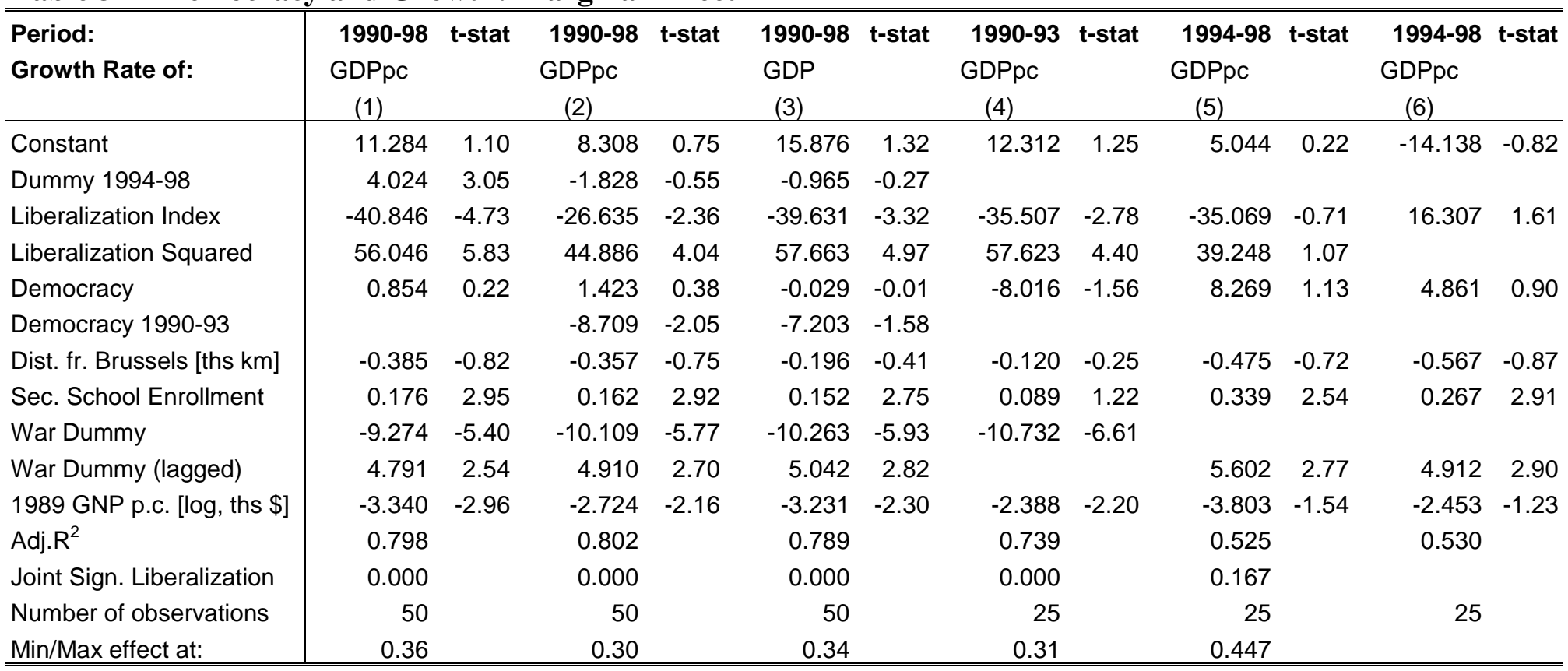

Notes: Estimated by OLS with heteroskedasticity robust t-statistics, for the 25 countries included in Table 1 . See also Notes to Table 2 . Democracy Index is the based on the average of political rights and civil liberties according to the Freedom House and normalized so that it ranges between zero and unity (see Notes to Table 1). The indices used in the regressions are the averages for the respective periods. Joint Significance Liberalization is the joint significance level of the liberalization index and its squared value. Minimum/Maximum effect refers to the level where the effect of liberalization reaches its minimum or maximum in the non-linear specification. 
Table 3B Democracy and Growth: Overall Effect

\begin{tabular}{|c|c|c|c|c|c|c|c|c|c|c|c|c|}
\hline $\begin{array}{l}\text { Period: } \\
\text { Growth Rate of: }\end{array}$ & $\begin{array}{c}\text { 1990-98 } \\
\text { GDPpc } \\
(7)\end{array}$ & t-stat & $\begin{array}{c}\text { 1990-98 } \\
\text { GDPpc } \\
(8)\end{array}$ & t-stat & $\begin{array}{l}\text { 1990-98 } \\
\text { GDP } \\
(9)\end{array}$ & t-stat & $\begin{array}{c}\text { 1990-93 } \\
\text { GDPpc } \\
(10)\end{array}$ & t-stat & $\begin{array}{c}\text { 1994-98 } \\
\text { GDPpc } \\
(11)\end{array}$ & t-stat & $\begin{array}{c}\text { 1994-98 } \\
\text { GDPpc } \\
(12)\end{array}$ & t-stat \\
\hline Dummy 1994-98 & 4.820 & 3.31 & -9.049 & -2.44 & -10.004 & -2.36 & & & & & & \\
\hline Residual Liberalization & 9.961 & 2.47 & 20.796 & 4.22 & 20.651 & 3.94 & 17.213 & 3.85 & 14.870 & 1.15 & 16.307 & 1.61 \\
\hline Res. Liberalization Sqrd. & 16.967 & 1.08 & 27.522 & 1.95 & 29.028 & 1.92 & 35.741 & 1.76 & 56.207 & 0.32 & & \\
\hline Dist. fr. Brussels [ths km] & 0.000 & 0.00 & -0.112 & -0.20 & 0.121 & 0.21 & 0.703 & 1.09 & -0.498 & -0.69 & -0.567 & -0.87 \\
\hline Sec. School Enrollment & 0.142 & 1.65 & 0.111 & 1.89 & 0.092 & 1.37 & 0.012 & 0.18 & 0.276 & 2.86 & 0.267 & 2.91 \\
\hline War Dummy & -8.022 & -3.60 & -10.631 & -5.22 & -10.853 & -4.95 & -11.331 & -5.35 & & & & \\
\hline War Dummy (lagged) & 3.714 & 2.05 & 4.496 & 2.64 & 4.492 & 2.73 & & & 5.083 & 2.88 & 4.912 & 2.90 \\
\hline 1989 GNP p.c. $[\log$, ths $\$]$ & -2.679 & -2.02 & -1.580 & -1.17 & -1.774 & -1.10 & -1.056 & -0.88 & -2.610 & -1.26 & -2.453 & -1.23 \\
\hline Min/Max effect at: & -0.29 & & -0.38 & & -0.36 & & -0.24 & & -0.132 & & & \\
\hline
\end{tabular}

Notes: Estimated by OLS with heteroskedasticity robust t-statistics, for the 25 countries included in Table 1 . See also Notes to Table 2 . Democracy Index is the based on the average of political rights and civil liberties according to the Freedom House and normalized so that it ranges between zero and unity (see Notes to Table 1). The indices used in the regressions are the averages for the respective periods. Joint Significance Liberalization is the joint significance level of the liberalization index and its squared value. Minimum/Maximum effect refers to the level where the effect of liberalization reaches its minimum or maximum in the non-linear specification. 
Table 4 Determinants of Democracy 1994-98

\begin{tabular}{|c|c|c|c|c|c|c|c|c|c|c|}
\hline $\begin{array}{l}\text { Dependent Variable } \\
\text { Democracy Index }\end{array}$ & $\begin{array}{c}\text { 1994-98 } \\
(1)\end{array}$ & t-stats & $\begin{array}{c}\text { 1994-98 } \\
(2) \\
\end{array}$ & t-stats & $\begin{array}{c}1994-98 \\
(3)\end{array}$ & t-stats & $\begin{array}{c}1994-98 \\
(4)\end{array}$ & t-stats & $\begin{array}{c}1994-98 \\
(5)\end{array}$ & t-stats \\
\hline Constant & -0.107 & -0.26 & 0.307 & 0.60 & -0.324 & -0.87 & 0.230 & 0.51 & 0.014 & 0.03 \\
\hline Liberalization 1990-93 & 0.623 & 3.45 & & & 0.919 & 6.10 & & & 0.150 & 0.79 \\
\hline Democracy 1990-93 & 0.512 & 2.39 & 1.034 & 4.50 & & & & & 0.815 & 2.68 \\
\hline Growth 1990-93 & -0.027 & -6.87 & -0.019 & -5.03 & -0.030 & -6.31 & -0.015 & -2.43 & & \\
\hline Residual Growth 1990-93 & & & & & & & & & -0.021 & -2.38 \\
\hline Distance from Brussels [ths km] & -0.024 & -1.35 & -0.047 & -2.11 & -0.031 & -1.68 & -0.118 & -6.81 & -0.043 & -1.81 \\
\hline War Dummy & -0.342 & -5.42 & -0.200 & -5.22 & -0.419 & -5.56 & -0.235 & -2.97 & -0.046 & -0.91 \\
\hline 1989 GNP p.c. [log, ths \$] & 0.004 & 0.10 & -0.034 & -0.57 & 0.049 & 1.19 & 0.071 & 1.29 & 0.023 & 0.51 \\
\hline Adj. $R^{2}$ & 0.906 & & 0.856 & & 0.885 & & 0.672 & & 0.814 & \\
\hline
\end{tabular}

Notes: Estimated by OLS with heteroskedasticity robust t-statistics, for the 25 countries included in Table 1 . See also Notes to Table 2 . Democracy Index is based on the average of political rights and civil liberties according to the Freedom House and normalized so that it ranges between zero and unity (see Notes to Table 1). The indices used in the regressions are the averages for the respective periods. The liberalization index is from de Melo et al. (1996), as extended by Havrylyshyn et al. (1998). The democracy is based on indices of political freedoms and civil liberties reported by the Freedom House. Residual Growth is the component of the overall growth rate that cannot be attributed to the influences of economic liberalization, democracy, wars or initial conditions. It is determined as the residual from the following regression (heteroskedasticity-robust t-statistics in parenthesis):

$\mathrm{Grpc}_{90-93}=13.650(1.43)-31.659(2.42) * \mathrm{LI}_{90-93}+53.164(3.90) * \mathrm{LI}_{90-93}{ }^{2}-7.953(1.51) * \mathrm{DI}_{90-93}-0.036(0.07) * \mathrm{Dist}-11.019(6.61) * \mathrm{War}-1.773(1.66) * \mathrm{GNP}\left[\mathrm{Adj} . \mathrm{R}^{2}\right.$ $0.741]$

where Grpc stands for the growth rate of per-capita GDP, LI is the liberalization index, DI is the democracy index, Dist measures the distance from Brussels, War is the dummy for military conflicts, and GNP is the log of 1989 GNP. 
Table 5 Economic Performance and Election Results

\begin{tabular}{|c|c|c|c|c|c|c|}
\hline & $\begin{array}{l}\text { Pro-reform } \\
\text { Parties }\end{array}$ & t-stats & $\begin{array}{l}\text { Left wing + } \\
\text { Nationalists }\end{array}$ & t-stats & Incumbents & t-stats \\
\hline Constant & 8.736 & 0.84 & 39.338 & 3.42 & 1.720 & 0.09 \\
\hline Unemployment Rate & -1.966 & -5.86 & 1.943 & 4.18 & -1.103 & -3.21 \\
\hline Growth Rate & 0.381 & 1.40 & -0.265 & -0.90 & -0.349 & -1.01 \\
\hline Output $[1989=100]$ & 0.492 & 4.43 & -0.086 & -0.79 & 0.488 & 2.46 \\
\hline Avg. Inflation & 0.040 & 8.08 & -0.030 & -5.01 & 0.004 & 0.46 \\
\hline \multirow[t]{2}{*}{ Adj. $R^{2}$} & 0.785 & & 0.646 & & 0.365 & \\
\hline & $\begin{array}{c}\text { Pro-reform } \\
\text { Parties }\end{array}$ & t-stats & $\begin{array}{l}\text { Left wing + } \\
\text { Nationalists }\end{array}$ & t-stats & Incumbents & t-stats \\
\hline Constant & 12.444 & 2.03 & 23.098 & 2.52 & 12.051 & 0.67 \\
\hline Unemployment Rate & -1.979 & -5.64 & 1.939 & 4.25 & -1.095 & -3.03 \\
\hline Growth Rate & 0.364 & 1.59 & -0.445 & -1.92 & -0.212 & -0.57 \\
\hline Output [1989=100] & 0.379 & 4.43 & -0.200 & -2.72 & 0.612 & 2.48 \\
\hline Avg. Inflation & 0.037 & 10.46 & -0.030 & -9.02 & 0.005 & 0.73 \\
\hline Liberalization Index & -34.788 & -2.97 & 12.766 & 0.84 & 3.787 & 0.19 \\
\hline Democracy Index & 40.113 & 3.27 & 19.880 & 1.31 & -29.328 & -1.48 \\
\hline Adj. $R^{2}$ & 0.815 & & 0.687 & & 0.316 & \\
\hline
\end{tabular}

Notes: Estimated by OLS with heteroskedasticity robust t-statistics. Number of observations is 17. The parties are classified along two dimensions: pro-reform vs. left-wing and nationalists, and incumbent vs. other (not reported). Average vote shares are $35.6 \%$ for the pro-reform parties, $48.6 \%$ for the left wing and nationalists, and $32.8 \%$ for the incumbent. The dependent variable is the share of votes for parties in the respective category in elections in the Czech Republic (1992, 1996, 1998), Slovakia (1992, 1994, 1998), Hungary (1994, 1998), Poland (1993, 1997), Romania (1992, 1996), Bulgaria (1991, 1994, 1997), and Slovenia (1992, 1996). All explanatory variables pertain to the election year. See the Notes following Table 1 for definitions of individual explanatory variables.

Source of election data: Berglund et al. (1998). 


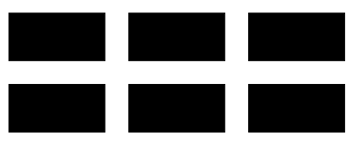

THE WiLliam DAVIDSON INSTITUTE

AT THE UNIVERSITY OF MICHIGAN BUSINESSSCHOOL

\section{DAVIDSON INSTITUTE WORKING PAPER SERIES - Most Recent Papers}

The entire Working Paper Series is available at: www.wdi.bus.umich.edu

CURRENT AS OF 4/25/01

\begin{tabular}{|c|c|c|}
\hline Publication & Authors & Date \\
\hline $\begin{array}{l}\text { No. } 372 \text { Economic Reform, Democracy and Growth During Post- } \\
\text { Communist Transition }\end{array}$ & Jan Fidrmuc & Mar. 2001 \\
\hline $\begin{array}{l}\text { No. } 371 \text { Do Multinational Enterprises Substitute Parent Jobs for Foreign } \\
\text { Ones? Evidence from Firm Level Panel Data }\end{array}$ & Jozef Konings & Apr. 2001 \\
\hline $\begin{array}{l}\text { No. } 370 \text { From Needs to the Market: Changing Inequality of Household } \\
\text { Income in the Czech Transition }\end{array}$ & Jiri Vecernik & Apr. 2001 \\
\hline $\begin{array}{l}\text { No. } 369 \text { Competition and Corporate Governance: Substitutes or } \\
\text { Complements? Evidence from the Warsaw Stock Exchange }\end{array}$ & $\begin{array}{l}\text { Irena Grosfeld and Thierry } \\
\text { Tressel }\end{array}$ & Mar. 2001 \\
\hline $\begin{array}{l}\text { No. } 368 \text { Multinational Corporations as Catalyst for Industrial } \\
\text { Development: The Case of Poland }\end{array}$ & $\begin{array}{l}\text { Carlo Altomonte and Laura } \\
\text { Resmini }\end{array}$ & Feb. 2001 \\
\hline No. 367 A Multi-Task Theory of the State Enterprise Reform & $\begin{array}{l}\text { Chong-En Bai, David D. Li, } \\
\text { Zhigang Tao, and Yijiang Wang }\end{array}$ & Mar. 2001 \\
\hline No. 366 Confidence Building in Emerging Stock Markets & $\begin{array}{l}\text { Enrico C. Perotti, Luc Laeven, } \\
\text { and Pieter van Oijen }\end{array}$ & Dec. 2000 \\
\hline $\begin{array}{l}\text { No. } 365 \text { Incentive Contracting versus Ownership Reforms: Evidence } \\
\text { from China's Township and Village Enterprises }\end{array}$ & $\begin{array}{l}\text { Chun Chang, Brian McCall, and } \\
\text { Yijang Wang }\end{array}$ & Nov. 2000 \\
\hline $\begin{array}{l}\text { No. } 364 \text { Individual Pay and Outside Options: Evidence from the Polish } \\
\text { Labour Force Survey }\end{array}$ & $\begin{array}{l}\text { Fiona Duffy and Patrick Paul } \\
\text { Walsh }\end{array}$ & Mar. 2001 \\
\hline $\begin{array}{l}\text { No. } 363 \text { Investment, Credit Rationing and the Soft Budget Constraint: } \\
\text { Evidence from Czech Panel Data (revised Davidson Institute Working } \\
\text { Paper No. 60a) }\end{array}$ & Lubomír Lízal and Jan Svejnar & Feb. 2001 \\
\hline $\begin{array}{l}\text { No. } 362 \text { A Network Perspective on Inter-Organizational Transfer of } \\
\text { R\&D Capabilities: A Study of International Joint Ventures in Chinese } \\
\text { Automobile Industry }\end{array}$ & $\begin{array}{l}\text { Zheng Zhao, Jaideep Anand and } \\
\text { Will Mitchell }\end{array}$ & Feb. 2001 \\
\hline $\begin{array}{l}\text { No. } 361 \text { Network Restructuring and Firm Creation in East-Central } \\
\text { Europe: A Public-Private Venture }\end{array}$ & Gerald A. McDermott & Dec. 2000 \\
\hline $\begin{array}{l}\text { No. } 360 \text { Responses of Private and Public Schools to Voucher Funding: } \\
\text { The Czech and Hungarian Experience }\end{array}$ & $\begin{array}{l}\text { Randall K. Filer and Daniel } \\
\text { Münich }\end{array}$ & Oct. 2000 \\
\hline $\begin{array}{l}\text { No. } 359 \text { Labor Market Uncertainty and Private Sector Labor Supply in } \\
\text { Russia }\end{array}$ & Steven Stillman & Sept. 2000 \\
\hline $\begin{array}{l}\text { No. } 358 \text { Russian Roulette-Expenditure Inequality and Instability in } \\
\text { Russia, 1994-1998 }\end{array}$ & Branko Jovanovic & Sept. 2000 \\
\hline No. 357 Dealing with the Bad Loans of the Chinese Banks & John P. Bonin and Yiping Huang & Jan. 2001 \\
\hline No. 356 Retail Banking in Hungary: A Foreign Affair? & John P. Bonin and István Ábel & Dec. 2000 \\
\hline $\begin{array}{l}\text { No. } 355 \text { Optimal Speed of Transition: Micro Evidence from the Czech } \\
\text { Republic }\end{array}$ & $\begin{array}{l}\text { Stepan Jurajda and Katherine } \\
\text { Terrell }\end{array}$ & Dec. 2000 \\
\hline No. 354 Political Instability and Growth in Dictatorships & $\begin{array}{l}\text { Jody Overland, Kenneth L. } \\
\text { Simons and Michael Spagat }\end{array}$ & Nov. 2000 \\
\hline No. 353 Disintegration and Trade & Jarko Fidrmuc and Jan Fidrmuc & Nov. 2000 \\
\hline $\begin{array}{l}\text { No. } 352 \text { Social Capital and Entrepreneurial Performance in Russia: A } \\
\text { Panel Study }\end{array}$ & Bat Batjargal & Dec. 2000 \\
\hline $\begin{array}{l}\text { No. } 351 \text { Entrepreneurial Versatility, Resources and Firm Performance in } \\
\text { Russia: A Panel Study }\end{array}$ & Bat Batjargal & Dec. 2000 \\
\hline $\begin{array}{l}\text { No. } 350 \text { The Dynamics of Entrepreneurial Networks in a Transitional } \\
\text { Economy: The Case of Russia }\end{array}$ & Bat Batjargal & Dec. 2000 \\
\hline
\end{tabular}




\begin{tabular}{|c|c|c|}
\hline $\begin{array}{l}\text { No. } 349 \text { R\&D and Technology Spillovers via FDI: Innovation and } \\
\text { Absorptive Capacity }\end{array}$ & Yuko Kinoshita & Nov. 2000 \\
\hline $\begin{array}{l}\text { No. } 348 \text { Microeconomic aspects of Economic Growth in Eastern } \\
\text { Europe and the Former Soviet Union, 1950-2000 }\end{array}$ & Sergei Guriev and Barry W. Ickes & Nov. 2000 \\
\hline $\begin{array}{l}\text { No. } 347 \text { Effective versus Statutory Taxation: Measuring Effective Tax } \\
\text { Administration in Transition Economies }\end{array}$ & $\begin{array}{l}\text { Mark E. Schaffer and Gerard } \\
\text { Turley }\end{array}$ & Nov. 2000 \\
\hline $\begin{array}{l}\text { No. } 346 \text { Objectives and Constraints of Entrepreneurs: Evidence from } \\
\text { Small and Medium Size Enterprises in Russia and Bulgaria }\end{array}$ & $\begin{array}{l}\text { Francesca Pissarides, Miroslav } \\
\text { Singer and Jan Svejnar }\end{array}$ & Oct. 2000 \\
\hline No. 345 Corruption and Anticorruption in the Czech Republic & $\begin{array}{l}\text { Lubomír Lízal and Evžen } \\
\text { Kočenda }\end{array}$ & Oct. 2000 \\
\hline No. 344 The Effects of Direct Foreign Investment on Domestic Firms & Jozef Konings & Oct. 2000 \\
\hline No. 343 On the Identification of Relative Wage Rigidity Dynamics & Patrick A. Puhani & Oct. 2000 \\
\hline $\begin{array}{l}\text { No. } 342 \text { The Determinants of Foreign Direct Investment in Transition } \\
\text { Economies }\end{array}$ & Alan A. Bevan and Saul Estrin & Oct. 2000 \\
\hline No. 341 The Global Spread of Stock Exchanges, 1980-1998 & Klaus Weber and Gerald F. Davis & Nov. 2000 \\
\hline $\begin{array}{l}\text { No. } 340 \text { The Costs and Benefits of Euro-isation in Central-Eastern } \\
\text { Europe Before or Instead of EMU Membership }\end{array}$ & D. Mario Nuti & Oct. 2000 \\
\hline No. 339 Debt Overhang and Barter in Russia & $\begin{array}{l}\text { Sergei Guriev, Igor Makarov and } \\
\text { Mathilde Maurel }\end{array}$ & Sept. 2000 \\
\hline $\begin{array}{l}\text { No. } 338 \text { Firm Performance and the Political Economy of Corporate } \\
\text { Governance: Survey Evidence for Bulgaria, Hungary, Slovakia and } \\
\text { Slovenia }\end{array}$ & $\begin{array}{l}\text { Patrick Paul Walsh and Ciara } \\
\text { Whela }\end{array}$ & July 2000 \\
\hline No. 337 Investment and Instability & $\begin{array}{l}\text { Nauro F. Campos and Jeffrey B. } \\
\text { Nugent }\end{array}$ & May 2000 \\
\hline $\begin{array}{l}\text { No. } 336 \text { The Evolution of the Insurance Sector in Central and } \\
\text { Eastern Europe and the former Soviet Union }\end{array}$ & Robert B.K. Pye & Aug. 2000 \\
\hline $\begin{array}{l}\text { No. } 335 \text { Institutional Technology and the Chains of Trust: Capital } \\
\text { Markets and Privatization in Russia and the Czech Republic }\end{array}$ & Bruce Kogut and Andrew Spicer & Aug. 2000 \\
\hline No. 334 The Evolution of Market Integration in Russia & $\begin{array}{l}\text { Daniel Berkowitz and David N. } \\
\text { DeJong }\end{array}$ & Aug. 2000 \\
\hline No. 333 Efficiency and Market Share in Hungarian Corporate Sector & László Halpern and Gábor Körösi & July 2000 \\
\hline No. 332 Search-Money-and-Barter Models of Financial Stabilization & $\begin{array}{l}\text { S.I. Boyarchenko and S.Z. } \\
\text { Levendorskii }\end{array}$ & July 2000 \\
\hline $\begin{array}{l}\text { No. } 331 \text { Worker Training in a Restructuring Economy: Evidence from } \\
\text { the Russian Transition }\end{array}$ & $\begin{array}{l}\text { Mark C. Berger, John S. Earle } \\
\text { and Klara Z. Sabirianova }\end{array}$ & Aug. 2000 \\
\hline $\begin{array}{l}\text { No. } 330 \text { Economic Development in Palanpur 1957-1993: A Sort of } \\
\text { Growth }\end{array}$ & Peter Lanjouw & Aug. 2000 \\
\hline $\begin{array}{l}\text { No. } 329 \text { Trust, Organizational Controls, Knowledge Acquisition from } \\
\text { the Foreign Parents, and Performance in Vietnamese International Joint } \\
\text { Ventures }\end{array}$ & $\begin{array}{l}\text { Marjorie A. Lyles, Le Dang } \\
\text { Doanh, and Jeffrey Q. Barden }\end{array}$ & June 2000 \\
\hline $\begin{array}{l}\text { No. } 328 \text { Comparative Advertising in the Global Marketplace: The } \\
\text { Effects of Cultural Orientation on Communication }\end{array}$ & $\begin{array}{l}\text { Zeynep Gürhan-Canli and } \\
\text { Durairaj Maheswaran }\end{array}$ & Aug. 2000 \\
\hline No. 327 Post Privatization Enterprise Restructuring & Morris Bornstein & July 2000 \\
\hline No. 326 Who is Afraid of Political Instability? & $\begin{array}{l}\text { Nauro F. Campos and Jeffrey B. } \\
\text { Nugent }\end{array}$ & July 2000 \\
\hline No. 325 Business Groups, the Financial Market and Modernization & Raja Kali & June 2000 \\
\hline $\begin{array}{l}\text { No. } 324 \text { Restructuring with What Success? A Case Study of Russian } \\
\text { Firms }\end{array}$ & Susan Linz & July 2000 \\
\hline $\begin{array}{l}\text { No. } 323 \text { Priorities and Sequencing in Privatization: Theory and } \\
\text { Evidence from the Czech Republic }\end{array}$ & $\begin{array}{l}\text { Nandini Gupta, John C. Ham and } \\
\text { Jan Svejnar }\end{array}$ & May 2000 \\
\hline $\begin{array}{l}\text { No. } 322 \text { Liquidity, Volatility, and Equity Trading Costs Across } \\
\text { Countries and Over Time }\end{array}$ & $\begin{array}{l}\text { Ian Domowitz, Jack Glen and } \\
\text { Ananth Madhavan }\end{array}$ & Mar. 2000 \\
\hline $\begin{array}{l}\text { No. } 321 \text { Equilibrium Wage Arrears: A Theoretical and Empirical } \\
\text { Analysis of Institutional Lock-In }\end{array}$ & $\begin{array}{l}\text { John S. Earle and Klara Z. } \\
\text { Sabirianova }\end{array}$ & Oct. 2000 \\
\hline No. 320 Rethinking Marketing Programs for Emerging Markets & $\begin{array}{l}\text { Niraj Dawar and Amitava } \\
\text { Chattopadhyay }\end{array}$ & June 2000 \\
\hline
\end{tabular}


No. 319 Public Finance and Low Equilibria in Transition Economies: the Role of Institutions

No. 318 Some Econometric Evidence on the Effectiveness of Active Labour Market Programmes in East Germany

No. 317 A Model of Russia's "Virtual Economy"

No. 316 Financial Institutions, Financial Contagion, and Financial Crises

No. 315 Privatization versus Regulation in Developing Economies: The Case of West African Banks

No. 314 Is Life More Risky in the Open? Household Risk-Coping and the Opening of China's Labor Markets

No. 313 Networks, Migration and Investment: Insiders and Outsiders in Tirupur's Production Cluster

No. 312 Computational Analysis of the Impact on India of the Uruguay Round and the Forthcoming WTO Trade Negotiations

No. 311 Subsidized Jobs for Unemployed Workers in Slovakia No. 310 Determinants of Managerial Pay in the Czech Republic

No. 309 The Great Human Capital Reallocation: An Empirical Analysis of Occupational Mobility in Transitional Russia

No. 308 Economic Development, Legality, and the Transplant Effect

No. 307 Community Participation, Teacher Effort, and Educational Outcome: The Case of El Salvador's EDUCO Program

No. 306 Gender Wage Gap and Segregation in Late Transition No. 305 The Gender Pay Gap in the Transition from Communism: Some Empirical Evidence

No. 304 Post-Unification Wage Growth in East Germany

No. 303 How Does Privatization Affect Workers? The Case of the

Russian Mass Privatization Program

No. 302 Liability for Past Environmental Contamination and Privatization

No. 301 Varieties, Jobs and EU Enlargement

No. 300 Employer Size Effects in Russia

No. 299 Information Complements, Substitutes, and Strategic Product Design

No. 298 Markets, Human Capital, and Inequality: Evidence from Rural China

No. 297 Corporate Governance in the Asian Financial Crisis

No. 296 Competition and Firm Performance: Lessons from Russia No. 295 Wage Determination in Russia: An Econometric Investigation

No. 294 Can Banks Promote Enterprise Restructuring?: Evidence From a Polish Bank's Experience

No. 293 Why do Governments Sell Privatised Companies Abroad?

No. 292 Going Public in Poland: Case-by-Case Privatizations, Mass Privatization and Private Sector Initial Public Offerings

No. 291a Institutional Technology and the Chains of Trust: Capital Markets and Privatization in Russia and the Czech Republic

No. 291 Institutional Technology and the Chains of Trust: Capital

Markets and Privatization in Russia and the Czech Republic

\begin{tabular}{|c|c|}
\hline $\begin{array}{l}\text { Daniel Daianu and Radu } \\
\text { Vranceanu }\end{array}$ & June 2000 \\
\hline $\begin{array}{l}\text { Martin Eichler and Michael } \\
\text { Lechner }\end{array}$ & June 2000 \\
\hline R.E Ericson and B.W Ickes & May 2000 \\
\hline $\begin{array}{l}\text { Haizhou Huang and Chenggang } \\
\mathrm{Xu}\end{array}$ & Mar. 2000 \\
\hline $\begin{array}{l}\text { Jean Paul Azam, Bruno Biais, and } \\
\text { Magueye Dia }\end{array}$ & Feb. 2000 \\
\hline John Giles & Apr. 2000 \\
\hline $\begin{array}{l}\text { Abhijit Banerjee and Kaivan } \\
\text { Munshi }\end{array}$ & Mar. 2000 \\
\hline $\begin{array}{l}\text { Rajesh Chadha, Drusilla K. } \\
\text { Brown, Alan V. Deardorff and } \\
\text { Robert M. Stern }\end{array}$ & Mar. 2000 \\
\hline Jan. C. van Ours & May 2000 \\
\hline $\begin{array}{l}\text { Tor Eriksson, Jaromir Gottvald } \\
\text { and Pavel Mrazek }\end{array}$ & May 2000 \\
\hline Klara Z. Sabirianova & Oct. 2000 \\
\hline $\begin{array}{l}\text { Daniel Berkowitz, Katharina } \\
\text { Pistor, and Jean-Francois Richard }\end{array}$ & Feb. 2000 \\
\hline Yasuyuki Sawada & Nov. 1999 \\
\hline Stepan Jurajda & May 2000 \\
\hline Andrew Newell and Barry Reilly & May 2000 \\
\hline Jennifer Hunt & Nov. 1998 \\
\hline Elizabeth Brainerd & May 2000 \\
\hline Dietrich Earnhart & Mar. 2000 \\
\hline $\begin{array}{l}\text { Tito Boeri and Joaquim Oliveira } \\
\text { Martins }\end{array}$ & May 2000 \\
\hline Todd Idson & Apr. 2000 \\
\hline $\begin{array}{l}\text { Geoffrey G. Parker and Marshall } \\
\text { W. Van Alstyne }\end{array}$ & Mar. 2000 \\
\hline $\begin{array}{l}\text { Dwayne Benjamin, Loren Brandt, } \\
\text { Paul Glewwe, and Li Guo }\end{array}$ & May 2000 \\
\hline $\begin{array}{l}\text { Simon Johnson, Peter Boone, } \\
\text { Alasdair Breach, and Eric } \\
\text { Friedman }\end{array}$ & Nov. 1999 \\
\hline J. David Brown and John S. Earle & Mar. 2000 \\
\hline $\begin{array}{l}\text { Peter J. Luke and Mark E. } \\
\text { Schaffer }\end{array}$ & Mar. 2000 \\
\hline John P. Bonin and Bozena Leven & Mar. 2000 \\
\hline $\begin{array}{l}\text { Bernardo Bortolotti, Marcella } \\
\text { Fantini and Carlo Scarpa }\end{array}$ & Mar. 2000 \\
\hline Wolfgang Aussenegg & Dec. 1999 \\
\hline Bruce Kogut and Andrew Spicer & Feb. 2001 \\
\hline Bruce Kogut and Andrew Spicer & Mar. 1999 \\
\hline
\end{tabular}




\begin{tabular}{|c|c|c|}
\hline No. 290 Banking Crises and Bank Rescues: The Effect of Reputation & Jenny Corbett and Janet Mitchell & Jan. 2000 \\
\hline $\begin{array}{l}\text { No. } 289 \text { Do Active Labor Market Policies Help Unemployed Workers to } \\
\text { Find and Keep Regular Jobs? }\end{array}$ & Jan C. van Ours & Feb. 2000 \\
\hline No. 288 Consumption Patterns of the New Elite in Zimbabwe & Russell Belk & Feb. 2000 \\
\hline $\begin{array}{l}\text { No. } 287 \text { Barter in Transition Economies: Competing Explanations } \\
\text { Confront Ukranian Data }\end{array}$ & $\begin{array}{l}\text { Dalia Marin, Daniel Kaufmann } \\
\text { and Bogdan Gorochowskij }\end{array}$ & Jan. 2000 \\
\hline $\begin{array}{l}\text { No. } 286 \text { The Quest for Pension Reform: Poland's Security through } \\
\text { Diversity }\end{array}$ & $\begin{array}{l}\text { Marek Góra and Michael } \\
\text { Rutkowski }\end{array}$ & Jan. 2000 \\
\hline No. 285 Disorganization and Financial Collapse & $\begin{array}{l}\text { Dalia Marin and Monika } \\
\text { Schnitzer }\end{array}$ & Oct. 1999 \\
\hline No. 284 Coordinating Changes in M-form and U-form Organizations & $\begin{array}{l}\text { Yingyi Qian, Gérard Roland and } \\
\text { Chenggang Xu }\end{array}$ & May 1999 \\
\hline $\begin{array}{l}\text { No. } 283 \text { Why Russian Workers Do Not Move: Attachment of Workers } \\
\text { Through In-Kind Payments }\end{array}$ & Guido Friebel and Sergei Guriev & Oct. 1999 \\
\hline No. 282 Lessons From Fiascos in Russian Corporate Governance & $\begin{array}{l}\text { Merritt B. Fox and Michael A. } \\
\text { Heller }\end{array}$ & Oct. 1999 \\
\hline $\begin{array}{l}\text { No. } 281 \text { Income Distribution and Price Controls: Targeting a Social } \\
\text { Safety Net During Economic Transition }\end{array}$ & $\begin{array}{l}\text { Michael Alexeev and James } \\
\text { Leitzel }\end{array}$ & Mar. 1999 \\
\hline $\begin{array}{l}\text { No. 280: Starting Positions, Reform Speed, and Economic Outcomes in } \\
\text { Transitioning Economies }\end{array}$ & William Hallagan and Zhang Jun & Jan. 2000 \\
\hline No. 279: The Value of Prominent Directors & $\begin{array}{l}\text { Yoshiro Miwa \& J. Mark } \\
\text { Ramseyer }\end{array}$ & Oct. 1999 \\
\hline No. 278: The System Paradigm & János Kornai & Apr. 1998 \\
\hline $\begin{array}{l}\text { No. 277: The Developmental Consequences of Foreign Direct } \\
\text { Investment in the Transition from Socialism to Capitalism: The } \\
\text { Performance of Foreign Owned Firms in Hungary }\end{array}$ & Lawrence Peter King & Sept. 1999 \\
\hline $\begin{array}{l}\text { No. 276: Stability and Disorder: An Evolutionary Analysis of Russia's } \\
\text { Virtual Economy }\end{array}$ & $\begin{array}{l}\text { Clifford Gaddy and Barry W. } \\
\text { Ickes }\end{array}$ & Nov. 1999 \\
\hline $\begin{array}{l}\text { No. 275: Limiting Government Predation Through Anonymous } \\
\text { Banking: A Theory with Evidence from China. }\end{array}$ & $\begin{array}{l}\text { Chong-En Bai, David D. Li, } \\
\text { Yingyi Qian and Yijiang Wang }\end{array}$ & July 1999 \\
\hline No. 274: Transition with Labour Supply & Tito Boeri & Dec. 1999 \\
\hline $\begin{array}{l}\text { No. 273: Sectoral Restructuring and Labor Mobility: A Comparative } \\
\text { Look at the Czech Republic }\end{array}$ & Vit Sorm and Katherine Terrell & Nov. 1999 \\
\hline $\begin{array}{l}\text { No. 272: Published in: Journal of Comparative Economics "Returns to } \\
\text { Human Capital Under the Communist Wage Grid and During the } \\
\text { Transition to a Market Economy" Vol. 27, pp. 33-60 } 1999 .\end{array}$ & $\begin{array}{l}\text { Daniel Munich, Jan Svejnar and } \\
\text { Katherine Terrell }\end{array}$ & Oct. 1999 \\
\hline $\begin{array}{l}\text { No. 271: Barter in Russia: Liquidity Shortage Versus Lack of } \\
\text { Restructuring }\end{array}$ & $\begin{array}{l}\text { Sophie Brana and Mathilde } \\
\text { Maurel }\end{array}$ & June 1999 \\
\hline $\begin{array}{l}\text { No. 270: Tests for Efficient Financial Intermediation with Application to } \\
\text { China }\end{array}$ & Albert Park and Kaja Sehrt & Mar. 1999 \\
\hline $\begin{array}{l}\text { No. 269a: Russian Privatization and Corporate Governance: What Went } \\
\text { Wrong? }\end{array}$ & $\begin{array}{l}\text { Bernard Black, Reinier Kraakman } \\
\text { and Anna Tarassova }\end{array}$ & May 2000 \\
\hline $\begin{array}{l}\text { No. 269: Russian Privatization and Corporate Governance: What Went } \\
\text { Wrong? }\end{array}$ & $\begin{array}{l}\text { Bernard Black, Reinier Kraakman } \\
\text { and Anna Tarassova }\end{array}$ & Sept. 1999 \\
\hline No. 268: Are Russians Really Ready for Capitalism? & Susan Linz & Sept. 1999 \\
\hline No. 267: Do Stock Markets Promote Economic Growth? & $\begin{array}{l}\text { Randall K. Filer, Jan Hanousek } \\
\text { and Nauro Campos }\end{array}$ & Sept. 1999 \\
\hline $\begin{array}{l}\text { No. 266: Objectivity, Proximity and Adaptability in Corporate } \\
\text { Governance }\end{array}$ & $\begin{array}{l}\text { Arnoud W.A Boot and Jonathan } \\
\text { R. Macey }\end{array}$ & Sept. 1999 \\
\hline $\begin{array}{l}\text { No. 265: When the Future is not What it Used to Be: Lessons from the } \\
\text { Western European Experience to Forecasting Education and Training in } \\
\text { Transitional Economies }\end{array}$ & $\begin{array}{l}\text { Nauro F. Campos, Gerard } \\
\text { Hughes, Stepan Jurajda, and } \\
\text { Daniel Munich }\end{array}$ & Sept. 1999 \\
\hline $\begin{array}{l}\text { No. 264: The Institutional Foundation of Foreign-Invested Enterprises } \\
\text { (FIEs) in China }\end{array}$ & Yasheng Huang & Sept. 1999 \\
\hline $\begin{array}{l}\text { No. 263: The Changing Corporate Governance Paradigm: Implications } \\
\text { for Transition and Developing Countries }\end{array}$ & $\begin{array}{l}\text { Erik Berglof and Ernst-Ludwig } \\
\text { von Thadden }\end{array}$ & June 1999 \\
\hline
\end{tabular}


The entire Working Paper Series is available at: www.wdi.bus.umich.edu

\begin{tabular}{|c|c|c|}
\hline No. 262: Law Enforcement and Transition & $\begin{array}{l}\text { Gerard Roland and Thierry } \\
\text { Verdier }\end{array}$ & May 1999 \\
\hline $\begin{array}{l}\text { No. 261: Soft Budget Constraints, Pecuniary Externality, and the Dual } \\
\text { Track System }\end{array}$ & Jiahua Che & June 2000 \\
\hline $\begin{array}{l}\text { No. 260: Missing Market in Labor Quality: The Role of Quality Markets } \\
\text { in Transition }\end{array}$ & Gary H. Jefferson & July 1999 \\
\hline $\begin{array}{l}\text { No. 259: Do Corporate Global Environmental Standards in Emerging } \\
\text { Markets Create or Destroy Market Value }\end{array}$ & $\begin{array}{l}\text { Glen Dowell, Stuart Hart and } \\
\text { Bernard Yeung }\end{array}$ & June 1999 \\
\hline No. 258: Public Training and Outflows from Unemployment & Patrick A. Puhani & June 1999 \\
\hline $\begin{array}{l}\text { No. 257: Ownership Versus Environment: Why are Public Sector Firms } \\
\text { Inefficient? }\end{array}$ & $\begin{array}{l}\text { Ann P. Bartel and Ann E. } \\
\text { Harrison }\end{array}$ & June 1999 \\
\hline $\begin{array}{l}\text { No. 256: Taxation and Evasion in the Presence of Exortion by } \\
\text { Organized Crime }\end{array}$ & $\begin{array}{l}\text { Michael Alexeev, Eckhard Janeba } \\
\text { and Stefan Osborne }\end{array}$ & Nov. 1999 \\
\hline No. 255: Revisiting Hungary’s Bankruptcy Episode & $\begin{array}{l}\text { John P. Bonin and Mark E. } \\
\text { Schaffer }\end{array}$ & Sept. 1999 \\
\hline No. 254: FDI in Emerging Markets: A Home-Country View & Marina v.N Whitman & June 1999 \\
\hline $\begin{array}{l}\text { No. 253: The Asian Financial Crisis: What Happened, and What is to be } \\
\text { Done }\end{array}$ & $\begin{array}{l}\text { Jeffrey D. Sachs and Wing Thye } \\
\text { Woo }\end{array}$ & Jan. 1999 \\
\hline No. 252: Organizational Law as Asset Partitioning & $\begin{array}{l}\text { Henry Hansmann and Reinier } \\
\text { Kraakman }\end{array}$ & Sept. 1999 \\
\hline $\begin{array}{l}\text { No. 251: Consumer Behav } \\
\text { the Case of the Optimum }\end{array}$ & $\begin{array}{l}\text { Jan-Benedict E. M. Steenkamp } \\
\text { and Steven M. Burgess }\end{array}$ & Sept. 1999 \\
\hline $\begin{array}{l}\text { No. 250: Property Rights Formation and the Organization of Exchange } \\
\text { and Production in Rural China }\end{array}$ & $\begin{array}{l}\text { Matthew A. Turner, Loren } \\
\text { Brandt, and Scott Rozelle }\end{array}$ & July 1998 \\
\hline $\begin{array}{l}\text { No. 249: Impacts of the Indonesian Economic Crisis: Price Changes and } \\
\text { the Poor }\end{array}$ & $\begin{array}{l}\text { James Levinsohn, Ste } \\
\text { and Jed Friedman }\end{array}$ & June 1999 \\
\hline $\begin{array}{l}\text { No. 248: Internal Barriers in the Transition of Enterprises from Central } \\
\text { Plan to Market }\end{array}$ & Charalambos Vlachoutsicos & July 1999 \\
\hline $\begin{array}{l}\text { No. 247: Spillovers from Multinationals in Developing Countries: the } \\
\text { Mechanisms at Work }\end{array}$ & Richard E. Caves & June 1999 \\
\hline $\begin{array}{l}\text { No. 246: Dynamism and Inertia on the Russian Labour Market: A } \\
\text { Model of Segmentation }\end{array}$ & $\begin{array}{l}\text { Irena Grosfeld, Claudia Senik- } \\
\text { Leygonie, Thierry Verdier, Stanislav } \\
\text { Kolenikov and Elena Paltseva }\end{array}$ & May 1999 \\
\hline No. 245: Lessons from Bank Privatization & John Bonin and Paul Wachtel & May 1999 \\
\hline $\begin{array}{l}\text { No. 244: Nominal-Real Tradeoffs and the Effects of Monetary Policy: } \\
\text { the Romanian Experience }\end{array}$ & Christian Popa & Dec. 1998 \\
\hline $\begin{array}{l}\text { No. 243: Privatization, Political Risk and Stock Market Development in } \\
\text { Emerging Economies }\end{array}$ & $\begin{array}{l}\text { Enrico C. Perotti and Pieter van } \\
\text { Oijen }\end{array}$ & Mar. 1999 \\
\hline No. 242: Investment Financing in Russian Financial-Industrial Groups & $\begin{array}{l}\text { Enrico C. Perotti and Stanislav } \\
\text { Gelfer }\end{array}$ & Oct. 1998 \\
\hline $\begin{array}{l}\text { No. 241: Can governments maintain hard budget constraints? Bank } \\
\text { lending and financial isolation in Romania }\end{array}$ & $\begin{array}{l}\text { Octavian Carare, Constantijn } \\
\text { Claessens, Enrico C. Perotti }\end{array}$ & Jan. 1999 \\
\hline $\begin{array}{l}\text { No. 240: Democratic Institutions and Economic Reform: the Polish } \\
\text { Case }\end{array}$ & $\begin{array}{l}\text { Jacek Klich, and } \\
\text { ska }\end{array}$ & Apr. 1998 \\
\hline No. 239: A Longitudinal Study of IJV Performance in Eastern Europe & $\begin{array}{l}\text { Keith D. Brouthers and Gary } \\
\text { Bamossy }\end{array}$ & June 1999 \\
\hline $\begin{array}{l}\text { No. 238: Published in: Journal of Business Venturing, "Firm Creation } \\
\text { and Economic Transitions" } 14 \text { (5,6) Sep/Nov 1999, pp. 427-450. }\end{array}$ & $\begin{array}{l}\text { John E. Jackson, Jacek Klich, } \\
\text { Krystyna Poznanska }\end{array}$ & July 1998 \\
\hline No. 237: Analysis of Entrepreneurial Attitudes in Poland & $\begin{array}{l}\text { John E. Jackson and Aleksander } \\
\text { S. Marcinkowski }\end{array}$ & Mar. 1997 \\
\hline $\begin{array}{l}\text { No. 236: Investment and Finance in De Novo Private Firms: Empirical } \\
\text { Results from the Czech Republic, Hungary, and Poland }\end{array}$ & $\begin{array}{l}\text { Andrzej Bratkowski, Irena } \\
\text { Grosfeld, Jacek Rostowski }\end{array}$ & Apr. 1999 \\
\hline $\begin{array}{l}\text { No. 235: Does a Soft Macroeconomic Environment Induce } \\
\text { Restructuring on the Microeconomic Level during the Transition } \\
\text { Period? Evidence from Investment Behavior of Czech Enterprises }\end{array}$ & Lubomír Lízal & June 1999 \\
\hline
\end{tabular}


The entire Working Paper Series is available at: www.wdi.bus.umich.edu

\begin{tabular}{|c|c|c|}
\hline $\begin{array}{l}\text { No. 234: Banking Reform in China: Gradually Strengthening Pillar or } \\
\text { Fragile Reed? }\end{array}$ & John Bonin & June 1999 \\
\hline $\begin{array}{l}\text { No. 233: Theories of Soft Budget Constraints and the Analysis of } \\
\text { Banking Crises }\end{array}$ & Janet Mitchell & Mar. 1999 \\
\hline $\begin{array}{l}\text { No. 232: Unemployment Risk, Precautionary Savings, and } \\
\text { Moonlighting in Russia }\end{array}$ & $\begin{array}{l}\text { Alessandra Guariglia and Byung- } \\
\text { Yeon Kim }\end{array}$ & June 1999 \\
\hline $\begin{array}{l}\text { No. 231: Investing in Turbulent Times: The Investment Behavior of } \\
\text { Polish Firms in the Transition }\end{array}$ & $\begin{array}{l}\text { Josef C. Brada, Arthur E. King, } \\
\text { and Chia-Ying Ma }\end{array}$ & Apr. 1999 \\
\hline No. 230: The End of Moderate Inflation in Three Transition Economies? & Josef C. Brada and Ali M. Kutan & Apr. 1999 \\
\hline $\begin{array}{l}\text { No. 229: Back to the Future: The Growth Prospects of Transition } \\
\text { Economies Reconsidered }\end{array}$ & Nauro F. Campos & Apr. 1999 \\
\hline No. 228: The Enterprise Isolation Program in Russia & Simeon Djankov & Apr. 1999 \\
\hline $\begin{array}{l}\text { No. 227: Published in: Journal of Comparative Economics, "Ownership } \\
\text { Concentration and Corporate Performance in the Czech Republic" } \\
\text { 27(3), Sept. 1999, pp. 498-513. }\end{array}$ & $\begin{array}{l}\text { Stijn Claessens and Simeon } \\
\text { Djankov }\end{array}$ & Apr. 1999 \\
\hline $\begin{array}{l}\text { No. 226: Published in Journal of Population Economics, "Poland on the } \\
\text { Dole: The Effect of Reducing the Unemployment Benefit Entitlement } \\
\text { Period during Transition" 13:35-44, } 2000 \text {. }\end{array}$ & Patrick A. Puhani & Mar. 1999 \\
\hline No. 225: Transition at Whirlpool-Tatramat: Case Studies & $\begin{array}{l}\text { Hans Brechbuhl and Sonia } \\
\text { Ferencikova }\end{array}$ & Mar. 1999 \\
\hline $\begin{array}{l}\text { No. 224: Measuring Progress in Transition and Towards EU Accession: } \\
\text { A Comparison of Manufacturing Firms in Poland, Romania, and Spain }\end{array}$ & $\begin{array}{l}\text { Wendy Carlin, Saul Estrin, and } \\
\text { Mark Schaffer }\end{array}$ & Mar. 1999 \\
\hline $\begin{array}{l}\text { No. 223: Product Market Competition in Transition Economies: } \\
\text { Increasing Varieties and Consumer Loyalty }\end{array}$ & Mitsutoshi M. Adachi & Mar. 1999 \\
\hline $\begin{array}{l}\text { No. 222: Opaque Markets and Rapid Growth: the Superiority of Bank- } \\
\text { Centered Financial Systems for Developing Nations }\end{array}$ & Rodney Wallace & July 1999 \\
\hline No. 221: Technology Spillovers through Foreign Direct Investment & Yuko Kinoshita & Jan. 1999 \\
\hline $\begin{array}{l}\text { No. 220: Managerial, Expertise and Team Centered Forms of } \\
\text { Organizing: A Cross-Cultural Exploration of Independence in } \\
\text { Engineering Work }\end{array}$ & Leslie Perlow & Jan. 1999 \\
\hline
\end{tabular}

